\title{
O PROJETO DE INTERVENCÃ̃O NA PóS-GRADUAÇÃO STRICTO SENSU: O ENSINO NOS ATELIESS DO MESTRADO PROFISSIONAL EM CONSERVAGÄO E RESTAURACG̃̃O DE MONUMENTOS E NÚCLEOS HISTÓRICOS DA UFBA
}

\section{BAETA, RODRIGO}

Arquiteto, Doutor, PPGAU UFBA, Coordenador do MP-CECRE UFBA, e-mail: rodrigobaeta@yahoo.com.br

\section{SANTANA, MARIELY CABRAL DE}

Arquiteta, Mestre, Vice Coordenadora do MP-CECRE UFBA, e-mail: mariely.santana@gmail.com

\section{CARDOSO, LULA}

Arquiteto, Doutor, Coordenador do PPGAU UFBA, ex-Coordenador do MP-CECRE UFBA, e-mail: Iulacard@gmail.com

\section{PINHEIRO, ELOISA PETTI}

Arquiteta, Doutora, ex-Coordenadora do MP-CECRE UFBA, e-mail: eloisapetti@gmail.com

\section{INTRODUÇÃO}

O Mestrado Profissional em Conservação e Restauração de Monumentos e Núcleos Históricos da Universidade Federal da Bahia (MP-CECRE UFBA) é um curso voltado a arquitetos e engenheiros civis brasileiros, latino-americanos, africanos lusófonos e portugueses. Foi aprovado pela CAPES (Coordenação de Aperfeiçoamento de Pessoal de Nível Superior) no final de 2009, tendo sua primeira edição iniciando em 2010. Não obstante, aproveitou toda a experiência precedente do Curso de Especialização em Conservação e Restauração de Monumentos e Sítios Históricos (CECRE), que foi promovido bienalmente pela Faculdade de Arquitetura da Universidade Federal da Bahia (FAUFBA) por cerca de 30 anos. Ao ser reconhecido como Mestrado Profissional, deu seguimento à formação de qualidade do curso de especialização, contando com um maior aprofundamento das questões teóricas e práticas, visando colocar no mercado novos mestres ainda mais qualificados para atuar no campo da preservação do patrimônio arquitetônico e urbanístico, sem dúvida, uma área fundamental dentre as políticas públicas contemporâneas.

\section{SÍNTESE HISTÓRICA}

O CECRE foi criado na década de 1970 por convênios celebrados entre a Secretaria de Cultura do MEC, Subsecretaria do Patrimônio Histórico e Artístico Nacional, Fundação Pró-Memória e diversas universidades brasileiras. A partir de sua quarta versão realizada em Salvador em 1981/1982, tornou-se um curso de alcance internacional, passando a contar também com a participação de alunos e consultores estrangeiros. Tendo em vista o sucesso desta versão - as primeiras edições aconteceram em São Paulo (1974), Recife (1976) e Belo Horizonte (1978) -, e atendendo a recomendações das demais instituições conveniadas, o curso passou a ter sede fixa na Universidade Federal da Bahia, através da sua Faculdade de Arquitetura e do Centro de Estudos da Arquitetura da Bahia (CEAB) - núcleo de pesquisa e extensão que passaria a acolher institucionalmente, fisicamente e academicamente o curso.

A inserção do CECRE em Salvador - e sua acolhida pela FAUFBA - foi de tal sucesso e envergadura que já em 1983 o CECRE deu origem, em conjunto com o Curso de Especialização em Planejamento Urbano e Regional (CEPUR), ao Mestrado Acadêmico em Arquitetura e Urbanismo (MAU UFBA), embrião do atual Programa de Pós-Graduação em Arquitetura e Urbanismo (PPGAU UFBA). 


\section{OBJETIVOS}

O MP-CECRE busca qualificar profissionais capacitados para responder às demandas das instituições públicas e empresas privadas que atuam na área da preservação de bens culturais, utilizando-se de uma sólida base teóricocrítica e de um intenso conhecimento empírico - uma vasta formação tecnológico-construtiva e criativa-projetual.

Para além disso, o curso busca:

- Oferecer um profundo conhecimento do patrimônio arquitetônico e urbanístico hispano-americano e lusobrasileiro, transmitindo aos alunos uma visão inovadora acerca das conceituações e metodologias de intervenções em monumentos e áreas de interesse histórico/cultural.

- Desenvolver conhecimentos sobre técnicas e sistemas construtivos, bem como sobre os seus comportamentos e respectivos materiais utilizados.

- Promover o conhecimento das teorias e técnicas de restauração, visando a preparação de projetos de conservação e restauro de monumentos e de recuperação de áreas degradadas.

- Demonstrar a prática de execução de obras do restauro e de intervenção em conjuntos urbanos.

- Formar as bases conceituais, científicas e tecnológicas indispensáveis à compreensão dos problemas da conservação e da restauração.

- Elaborar projetos e propostas de intervenção visando a recuperação dos temas estudados durante o curso, com base nos conhecimentos metodológicos adquiridos no decorrer do mesmo, de forma a permitir a utilização destas propostas por parte dos diversos organismos patrocinadores.

\section{SOBRE O TRABALHO FINAL DO MP-CECRE}

O Trabalho Final que os estudantes elaboram não deve ser confundido com uma dissertação de mestrado propriamente dita, apesar de todo embasamento teórico-crítico necessário para apoiar e justificar as decisões vinculadas ao conteúdo técnico e criativo elaborado(1). Na verdade, é um projeto arquitetônico ou de engenharia completo, que afeta a recuperação de uma preexistência edificada ou urbana de interesse cultural, com todos os aportes necessários para a sua aplicação efetiva: um trabalho profissional, desenvolvido durante os 24 meses do curso, com o apoio de inúmeros professores expertos na área, de diversos estados e países, bem como consultores de projeto que dão sua contribuição na orientação dos alunos.

Para isso, o tema proposto deve estar enquadrado em uma das seguintes categorias:

- Projetos de áreas ou conjuntos urbanos de interesse histórico e cultural - tendo como premissa a definição de critérios e diretrizes para a sua preservação e/ou requalificação.

- Projetos de restauração de edificações - que têm como objeto a restauração e adaptação de monumentos isolados (em sua interface com o contexto urbano preexistente), atendendo às novas dinâmicas contemporâneas.

- Projetos de conservação, consolidação ou restauração estrutural ou de instalações - ou seja, projetos de cunho tecnológico, geralmente desenvolvidas pelos alunos que ingressam no curso com a formação de engenharia.

\section{ESTRUTURA PEDAGÓGICA DO CURSO}

Enquanto estrutura curricular, o MP-CECRE possui um encaminhamento de disciplinas que funcionam como uma verdadeira espinha dorsal e que congrega todas as suas atividades de formação profissional: os Ateliês, divididos sequencialmente em três disciplinas de 136 horas aula, computando uma carga horária de 408 horas. 
Todas as outras disciplinas e atividades estão vinculadas, de uma forma ou de outra, à estrutura dos três ateliês. São quatro disciplinas teóricas obrigatórias compartilhadas com o PPGAU UFBA, essenciais para consolidar a instrumentação tecnológica, bem como o embasamento crítico necessário para a elaboração do projeto. Além disso, os alunos cumprem cinco créditos de disciplinas optativas escolhidas no rol daquelas oferecidas no PPGAU - necessariamente vinculadas à área da salvaguarda do patrimônio. No último semestre os discentes também frequentam estágio supervisionado em escritório de arquitetura ou engenharia que trabalhe com conservação e restauração do patrimônio edificado ou urbano, ou em órgãos oficiais voltados pra a preservação de bens culturais.

\section{OS ATELIÊS DE PROJETO}

Com a carga horária de 136 horas, o Atelier de Projeto I: levantamento de dados e análise de edifícios, conjuntos e sítios históricos é oferecido no primeiro semestre letivo do curso. É o ateliê responsável pela orientação dos alunos em prol da coleta e da sistematização de dados cadastrais referentes ao monumento ou sítio urbano de interesse cultural que traz como tema. Cumpre as atividades necessárias para a posterior identificação das patologias que afetam o objeto escolhido.

Primeiramente, o aluno é assistido na fase de coleta de dados, ao final da qual deve apresentar: investigação dos dados históricos do monumento ou núcleo urbano que deverá sofrer intervenção; identificação dos condicionantes tecnológicos; levantamento dos dados referentes às condições climáticas do local, vegetação, infraestrutura urbana e interferências do entorno; levantamento fotográfico (fotos antigas e vistas atuais).

Em um segundo momento, parte-se para a etapa decisiva que consiste no levantamento planialtimétrico da edificação ou área urbana, com a produção das peças gráficas considerando o atual estado de conservação do objeto. Deve-se desenvolver pelo menos: planta de localização do monumento ou conjunto urbano em relação ao seu entorno; planta de situação indicando a(s) edificação(s) do conjunto ou do lote; desenhos topográficos da área trabalhada ou do terreno e área envoltória, destacando edificações e vegetação; todas as plantas baixas, além de cortes, elevações e fachadas, com cotas e níveis dos ambientes representados ou trechos de rua; perfis das ruas e praças; detalhes arquitetônicos; detalhes construtivos (telhado, esquadrias, escadas, pisos, forros, estrutura, elementos decorativos).

Para que os alunos consigam elaborar esses produtos, a atividade se desenvolve a partir da abordagem teórica e prática por meio da utilização das seguintes técnicas de ensino:

- $\quad$ Atividades coletivas com discussão e exposição dos trabalhos - correspondente à apresentação dos processos metodológicos desenvolvidos por cada aluno e discussão dos principais problemas encontrados, propiciando um amplo debate sobre as diferentes temáticas apresentadas nas aulas expositivas e possibilidades de soluções.

- $\quad$ Apresentação dos diversos conteúdos referentes à historia e à teoria da arquitetura, aos sistemas construtivos, à análise ambiental e às técnicas de levantamentos planialtimétrico, ministrada por professores especialistas, tendo sempre como interface os temas específicos a serem defendidos pelos alunos.

- $\quad$ Aulas expositivas estruturadas a partir de autores brasileiros e estrangeiros que constituem referência para este campo de estudo, focalizando seus aspectos metodológicos e contribuições analíticas para a síntese dos dados coletados por cada aluno.

- $\quad$ Acompanhamento individual para análise e orientação especifica, respeitando as especificidades de cada objeto e suas características regionais.

Também com carga horária de 136 horas, o Ateliê de Projeto II - diagnóstico físico ambiental e conservação preventiva de edifícios, conjuntos e sítios históricos é a atividade responsável pela identificação e caracterização dos problemas ligados à conservação do edifico ou núcleo urbano.

Os danos já são previamente detectados durante o levantamento cadastral no Ateliê I, mas no Ateliê II 
eles são mostrados (fotografias), descritos (fichas fotográficas), indicados (plantas, cortes, fachadas com mapeamento de danos) - mas principalmente são perseguidos os motivos que levaram o edifício ou a área urbana a se degradar, a ter perdas, problemas estruturais, de estabilidade, de conservação, abandono, mutilação, vandalismo, acréscimos espúrios, problemas sociais ligados à ocupação dos edifícios e dos sítios, decadência econômica e social, problemas de infraestrutura, arruinamentos.

Ou seja, é o momento de se fazer a diagnose das patologias construtivas e arquitetônicas, no caso do objeto de trabalho ser um edifício, ou da identificação dos problemas de descaracterização, degradação social, abandono, decadência, fraturas na paisagem de conjuntos urbanos de interesse cultural e sítios históricos, artísticos, arqueológicos.

O Atelier de projeto III: projeto de intervenção em edifícios, conjuntos e sítios históricos, é a atividade conclusiva de assistência e orientação ao projeto. Oferecida no terceiro semestre letivo, com carga horária de 136 horas, é a ocasião em que os discentes reúnem todo o material trabalhado nos dois primeiros ateliês, assim como nos produtos finais das disciplinas cursadas: quando a carga de conhecimentos teóricos, tecnológicos, instrumentais e práticos se integra para embasar a discussão crítica e os procedimentos empíricos e de criatividade que envolvem a elaboração do projeto de intervenção propriamente dito - a partir dos fatores de degradação identificados no Ateliê II (diagnóstico) e com apoio do material sistematizado no Ateliê I (cadastro e coleta de dados).

Ou seja, como professa a ementa da disciplina (MP-CECRE, 2015, p. 32), dá apoio ao aluno no desenvolvimento do projeto de conservação, consolidação, restauração, requalificação, revitalização, reciclagem, renovação ou qualquer outra categoria de intervenção sobre a preexistência edificada ou urbana que o pós-graduando defina como estratégica para a recuperação de seu objeto de estudo.

\section{PRINCIPAIS RESULTADOS}

O MP-CECRE conta com três turmas já encerradas e com uma turma em curso. A diversidade regional e internacional dos alunos e ex-alunos, falando especificamente do mestrado profissional (desconsiderando os 264 trabalhos desenvolvidos nas doze versões do curso ministrado como especialização na Bahia, de 1981 a 2009), é imensa: Alagoas, Bahia, Maranhão, Mato Grosso, Mato Grosso do Sul, Minas Gerais, Pernambuco, Piauí, Rio de Janeiro, Rio Grande do Sul, São Paulo, Sergipe - mas também egressos e discentes de fora do Brasil: Argentina, Bolívia, Colômbia, Cuba, El Salvador, México.

Neste sentido, os resultados apresentados são plenamente consonantes ao Plano Nacional de Pós-Graduação - PNPG 2005-2010 (MEC, 2014) -, visto que o curso tem contribuído para a diminuição das assimetrias e desigualdades regionais, com a satisfação da meta de crescimento de titulação na área de Arquitetura e Urbanismo em diversos estados fora do eixo Rio-São Paulo, e em diversos países da América Ibérica.

Até outubro de 2016, foram atribuídos graus de mestre a 23 pós-graduandos. Dos trabalhos defendidos, 9 foram projetos que afetaram áreas urbanas ou conjuntos de interesse histórico e cultural, 12 projetos de intervenção em edificações e mais 1 projeto de instalação em área urbana. Os temas escolhidos para a elaboração dos trabalhos finais preenchem as principais fases da arquitetura ibero-americana: período colonial, imperial, arquitetura do ecletismo, belle époque, arquitetura art déco e futurista, movimento moderno, arquitetura contemporânea. Também é grande a diversidade tipológica: arquitetura religiosa (igrejas e conventos), residencial, industrial, chafarizes, hospedaria, edifícios institucionais, escolas, arquitetura rural, cine-teatro, estação rodoviária, centros históricos consolidados do período colonial e do ecletismo (Quadro 1).

Ilustrando essa produção, exibiremos a seguir seis das propostas defendidas no MP-CECRE, aqui apresentadas pelos seus próprios autores. É bom dizer que a síntese dos trabalhos finais contempla apenas, de forma imensamente resumida, uma das três grandes etapas da elaboração dos trabalhos, coincidentes com os três ateliês - a etapa final de desenvolvimento do projeto de intervenção, equivalente ao Ateliê III. 
TURMA DE 2010 (EGRESSOS DE 2011):

1. CAMILA MEIRA BARBOSA MARQUES

Requalificação do Conjunto Urbanístico da Rua do Comércio, no Bairro do Centro em Maceió - Alagoas.

2. FERNANDA VIERNO DE MOURA

São Luiz do Paraitinga - São Paulo: Preservação do Centro Histórico e Intervenção na Praça Dr. Oswaldo Cruz.

3. MARCIA SILVA DOS REIS

Projeto de Intervenção do Edifício Sede Regional da CHESF em Salvador - Bahia.

4. MARCOS IVAN DA FONSECA GOMES

Colina Histórica de Igaraçu - Pernambuco. lluminação e Embutimento subterrâneo das Redes Aéreas.

5. MARIA ELISA CAMPOS PEREIRA

Requalificação da Praça Conde de Azambuja e seu Entorno. Cuiabá - Mato Grosso. Proposta de Melhoria para Área Histórica Residencial

6. MARISE FERREIRA ALVES

Projeto de Restauração e Adaptação de Uso ao Sobrado na Avenida Pedro II, 199 e 209, Quadra 04, Centro Histórico de São Luís - Maranhão.

7. OLIVIA MALFATTI BUSCARIOLLI

Hospedaria dos Imigrantes em Santos - São Paulo. Reconversão para Residência Universitária.

8. ROMULO AUGUSTO DRUMMOND

Conjunto Urbano da Cidade de Belmont - Bahia: Estudos para Instrução do Pedido de Tombamento Federal

9. VANIA AVELAR DE ALBUQUERQUE

Conservação e Restauração das Bicas Públicas de Olinda - Pernambuco: São Pedro, Quatro Cantos e Rosário Sistema Simplificado de Abastecimento de Água.

\section{TURMA DE 2012 (EGRESSOS DE 2013)}

10. ALAN HENRIQUE QUINTELLA

Projeto de Intervenção no Edifício dos Arquitetos. Sede do IAB-BA. Salvador - Bahia.

11. ALINE DOS SANTOS ROCHA

Adaptação do Edifício do Antigo Colégio Marista à Sede da Reitoria do IFBA. Salvador - Bahia.

12. CARMEN LUCIA MURARO

Projeto de Restauração da Casa-Grande da Fazenda Cachoeira do Taepe - Pernambuco: o Edifício e a Unidade Agropastoril.

13. FEDERICO CALABRESE

Estudos de Requalificação e Projeto de Valorização Urbana do Bairro Rio Vermelho, em Salvador - Bahia.

14. MILENA FRAGA DE AMORIM

Proposta de Restauração do Cine Teatro Jandaia, Salvador - Bahia.

15. TANIA NAMIKO KASHIWAKURA OLIVEIRA

Restauração da Antiga Casa dos Nogueira, em Valença - Rio de Janeiro.

\section{TURMA DE 2014 (EGRESSOS DE 2015)}

16. ALICIA GABRIELA CANDIA BARRIENTOS

Restauración del Convento Santa Teresa: Proyecto para la Escuela Superior de Bellas Artes en Cochabamba - Bolivia.

17. IVANA PERUCCI DOS SANTOS

Proposta de Requalificação para a Ladeira Santa Efigênia, Ouro Preto - Minas Gerais.

18. JULIA MIRANDA ALOISE

Revitalização do Núcleo Histórico de Mostardas - Rio Grande do Sul: normativas e projeto de intervenção no conjunto tradicional.

19. LORENE PAULINE OLIVEIRA

Projeto de Intervenção no Solar Bandeira, Salvador - Bahia.

20. LUZ AMARILY ARAUJO ESPINOZA

Directrices para la Preservación Integrada del Centro Antiguo de San Salvador - El Salvador.

21. MARIA EMILIA RODRIGUES REGINA

Reabilitação Arquitetônica do Conjunto Histórico da Igreja da Conceição da Praia, Salvador - Bahia. Passado, Presente e Futuro.

22. MARIA JULIA LINARES ROSALES

Restauración, Conservación e Intervención de la Casa Stoppel, Mendoza - Argentina.

23. RAQUEL NEIMANN DA CUNHA FREIRE

Requalificação da Antiga Estação Rodoviária de Salvador - Bahia. 


\section{NOTAS}

(1) Segundo o Artigo 7², Inciso VIII, Parágrafo 3', da Portaria Normativa do Ministério da Educação n 17, de 28 de dezembro de 2009 , que dispõe sobre o Mestrado Profissional no âmbito CAPES, o trabalho de conclusão não precisa ser uma dissertação de mestrado, podendo assumir outros formatos: "O trabalho de conclusão final do curso poderá ser apresentado em diferentes formatos, tais como dissertação, revisão sistemática e aprofundada da literatura, artigo, patente, registros de propriedade intelectual, projetos técnicos, publicações tecnológicas; desenvolvimento de aplicativos, de materiais didáticos e instrucionais e de produtos, processos e técnicas; produção de programas de mídia, editoria, composições, concertos, relatórios finais de pesquisa, softwares, estudos de caso, relatório técnico com regras de sigilo, manual de operação técnica, protocolo experimental ou de aplicação em serviços, proposta de intervenção em procedimentos clínicos ou de serviço pertinente, projeto de aplicação ou adequação tecnológica, protótipos para desenvolvimento ou produção de instrumentos, equipamentos e kits, projetos de inovação tecnológica, produção artística, sem prejuízo de outros formatos, de acordo com a natureza da área e a finalidade do curso, desde que previamente propostos e aprovados pela CAPES." (MEC, 2009, p. 21)

\section{REFERÊNCIAS}

MEC. Plano Nacional de Pós-Graduação (PNPG) 2005-2010. Brasília: MEC, 2014. Disponível em: https://www.capes.gov.br/images/stories/ download/editais/PNPG_2005_2010.pdf

MEC. Portaria Normativa do Ministério da Educação n 17, de 28 de dezembro de 2009. In: BRASIL. Diário Oficial da União. Brasília, 2009, n. 248, Seção I. Disponível em: http://www.capes.gov.br/images/stories/download/avaliacao/avaliacao-n/Port-MEC-17-2009-mestradoprofissional.pdf

MP-CECRE. Projeto para reformulação da estrutura curricular do MP-CECRE. MP-CECRE UFBA: Salvador, 2015. Disponível em: https://cecre. ufba.br/sites/cecre.ufba.br/files/proposta_de_reformulacao_curricular_do_mp-cecre.pdf

NOTA DO EDITOR (*) O conteúdo do artigo e as imagens nele publicadas são de responsabilidade do(s) autor(es). 


\title{
SÃO LUIZ DO PARATIINGA: PRESERVACG̃̃O DO CENTRO HISTÓRICO E INTERVENÇÃOO NA PRAÇA DR. OSWALDO CRUZ
}

\begin{abstract}
MOURA, FERNANDA VIERNO
Arquiteta, Mestre, Professora UNIFATEA, UNESP, Anhanguera; Email: fernandavierno@hotmail.com Trabalho Final desenvolvido no Mestrado Profissional em Conservação e Restauração de Monumentos e Núcleos Históricos da UFBA Orientador: Luiz Antonio Fernandes Cardoso
\end{abstract}

\section{RESUMO EXPANDIDO}

O centro histórico de São Luiz do Paraitinga, cidade paulista fundada em meados do século XVIII, surpreende seus visitantes pela unidade visual, pela homogeneidade do conjunto e pela regularidade e simetria das suas edificações. Essa harmonia estética tem origem no plano de ocupação do território, típico da época caracterizada como iluminista, que procurava tratar a arquitetura como consequência da planificação urbana, promovendo a uniformidade e o alinhamento das fachadas e buscando uma elegância estética, simétrica e regular do casario. A principal praça da cidade encontrava-se, na ocasião da elaboração do projeto de intervenção desenvolvido no MP-CECRE (MOURA, 2011), com lacunas urbanas, oriundas do desabamento de alguns edifícios após a ocorrência de uma grande enchente no local em janeiro de 2010. (Figura 1)

Figura 1 - Vista de parte do casario da Praça Oswaldo Cruz logo após a enchente de janeiro de 2010 mostrando um edifício de taipa de pilão e de mão inteiramente arruinado.

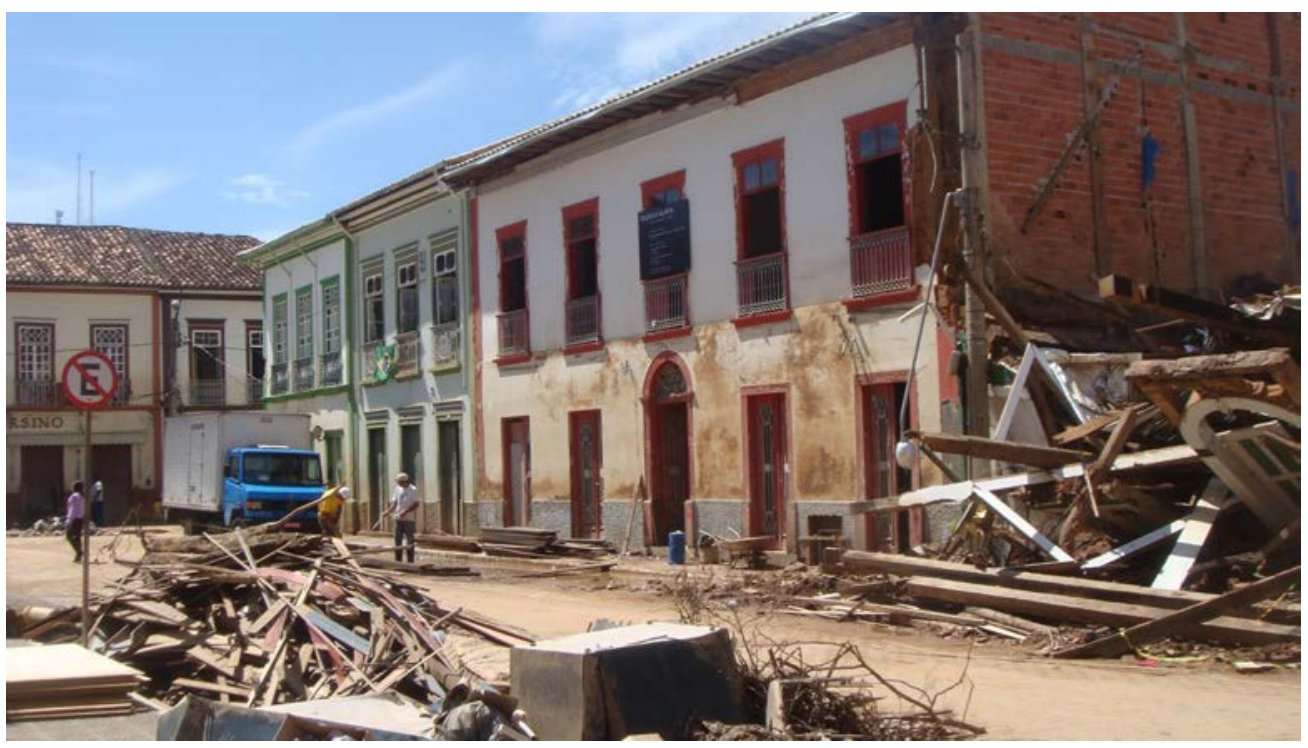

Fonte: Moura (2011).

Mas apesar da destruição causada, que arrasou parte do patrimônio arquitetônico da Praça Dr. Oswaldo Cruz, a uniformidade característica do casario século XIX ainda era possível de ser vista na configuração do cenário urbano (Figura 2). 
Figura 2 - Perímetro da área em estudo que envolve a Praça Dr. Oswaldo Cruz e casario ao seu redor, que corresponde ao espaço ocupado por 32 lotes.

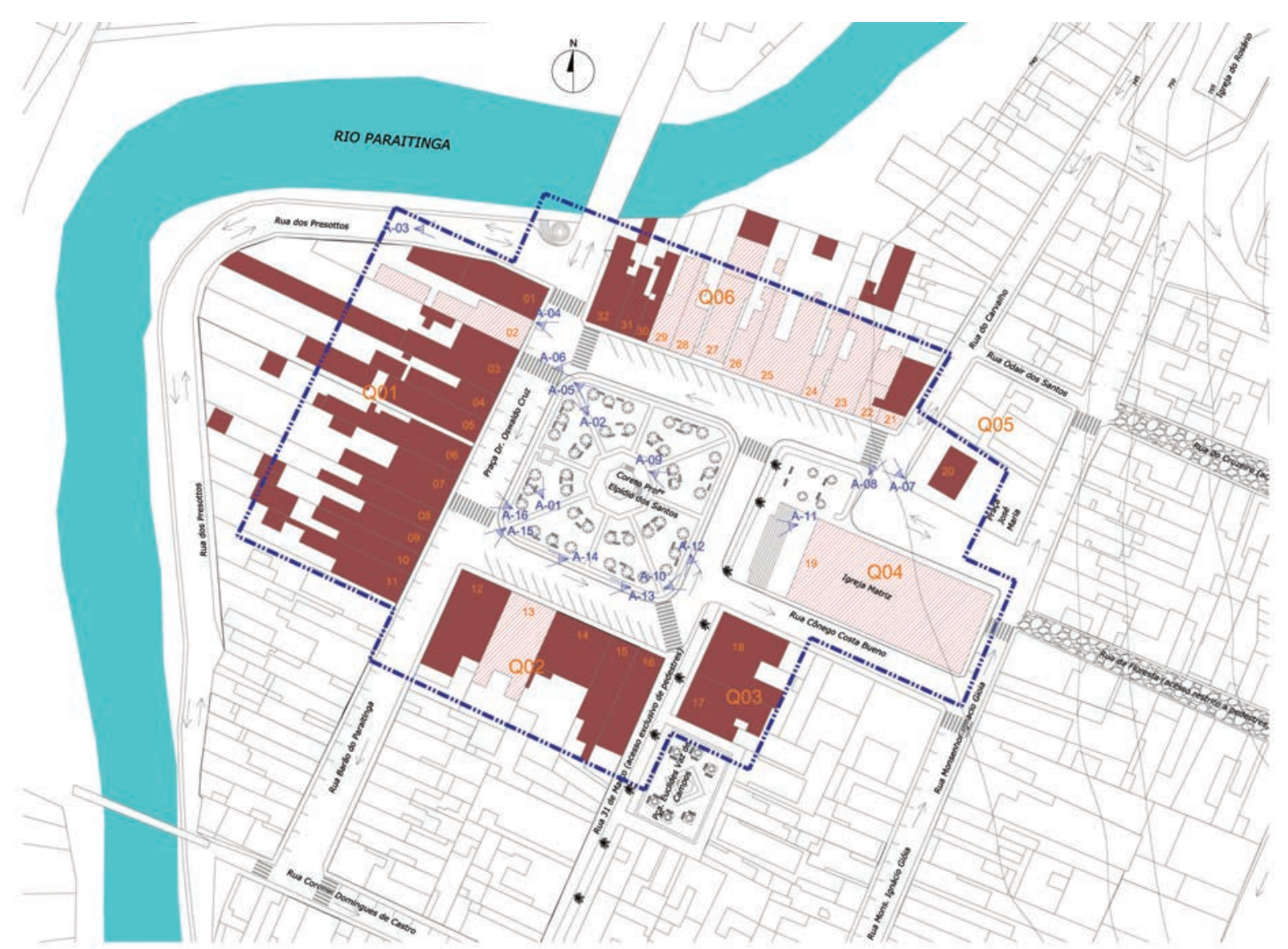

PRAÇA DR. OSWALDO CRUZ - LEGENDA

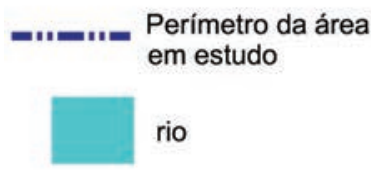

edificações

Q01 Numeração das quadras

edificações arruinadas $\quad 01 \quad$ Numeração dos lotes

Fonte: Moura (2011).

O desafio era entender como se devia intervir nesse rico ambiente histórico, visando a recomposição do que se perdeu, sem falsear o aspecto estético do conjunto e nem propor uma nova arquitetura que impunha sua presença sobre a anterior.

Entendeu-se que o conjunto preexistente jamais voltaria a existir, mas qualquer intervenção neste local deveria dialogar em harmonia com o ambiente histórico desta praça, já tão cheia de caráter. Além disso, a futura intervenção deveria ser testemunho da época em que se desenvolveu o projeto, documentando também as técnicas construtivas do presente.

Através de uma documentação arquitetônica da situação em que se encontrava a praça foi possível se ter a compreensão das características morfológicas e estéticas do local e identificar as tensões visuais existentes que deveriam ser eliminadas para recuperar a percepção deste ambiente por inteiro.

O mapeamento de cheios e vazios da área, nos mostrava que o vazio que se formou com as perdas totais era menor do que o tecido remanescente, o que permitia que a leitura parcial do conjunto urbano ainda fosse possível de ser feita. A situação contrária o condenaria à condição de ruína (Figuras 3-6). 
Figura 3 - Perfil e leitura dos cheios x vazios das edificações da quadra 01 com proposta de preenchimento da lacuna existente (em amarelo).
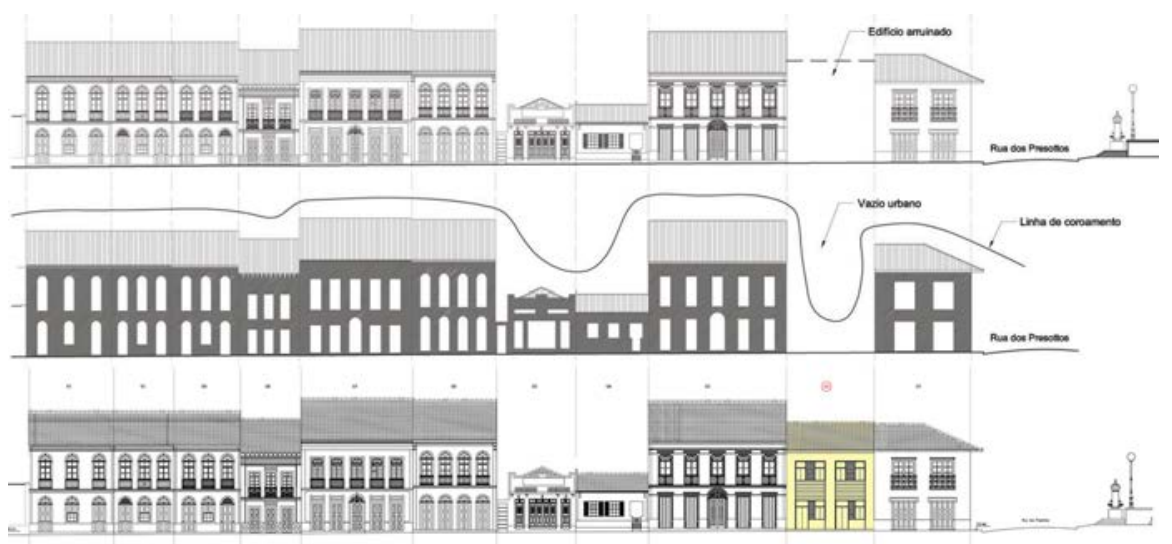

Fonte: Moura (2011).

Figura 4 - Perfil e leitura dos cheios x vazios das edificações da quadra 02 com proposta de preenchimento da lacuna existente (em amarelo).

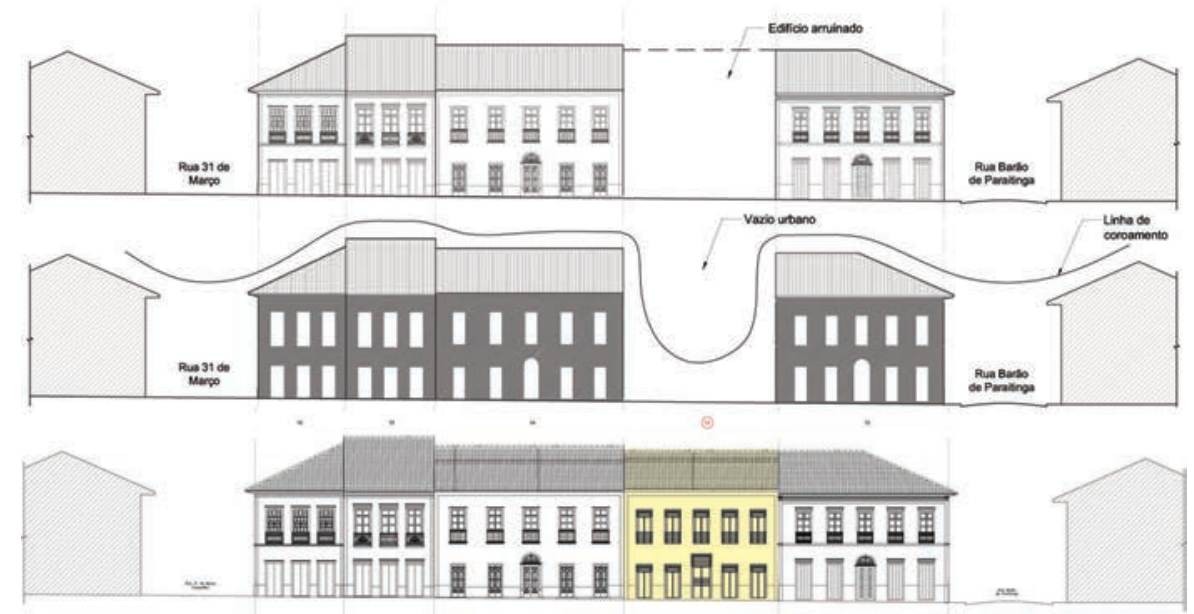

Fonte: Moura (2011).

Figura 5 - Perfil e leitura dos cheios x vazios das edificações das quadras 03, 04 e 05 com proposta de preenchimento da lacuna existente (em amarelo).

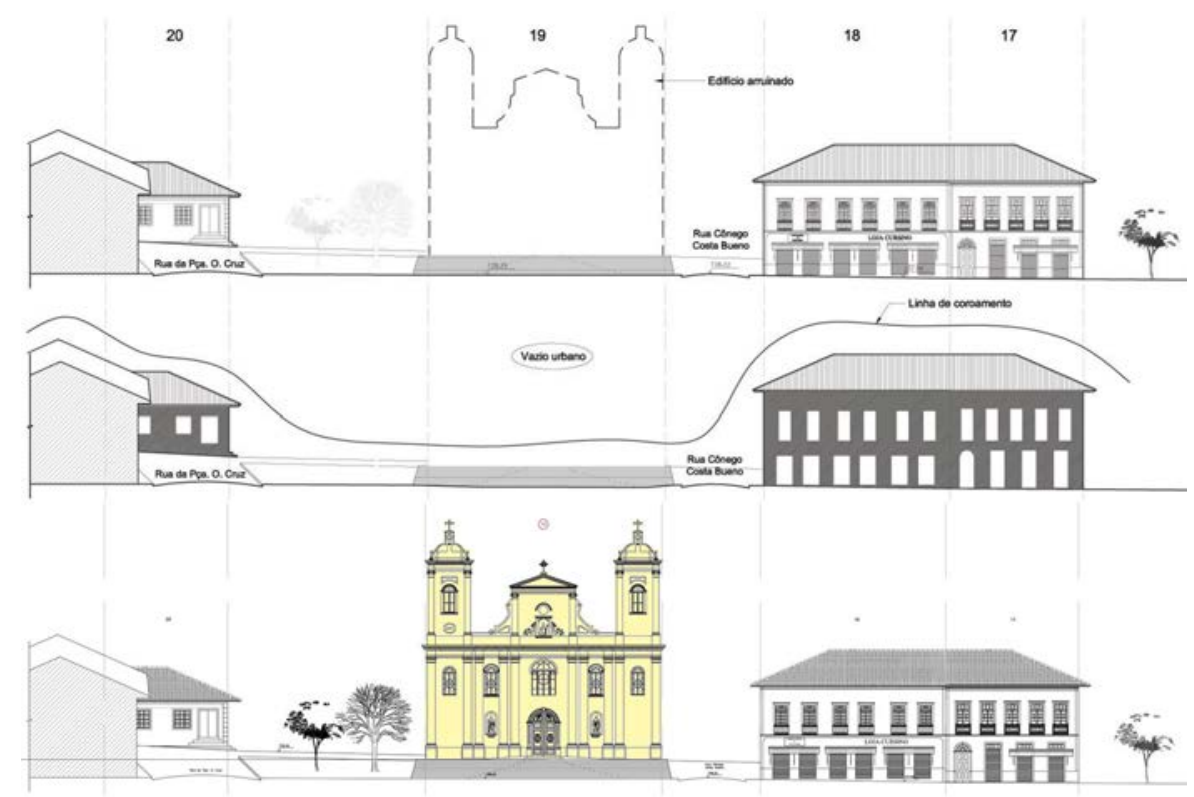

Fonte: Moura (2011). 
Figura 6 - Perfil e leitura dos cheios x vazios das edificações da quadra 06 com proposta de preenchimento da lacuna existente (em amarelo).

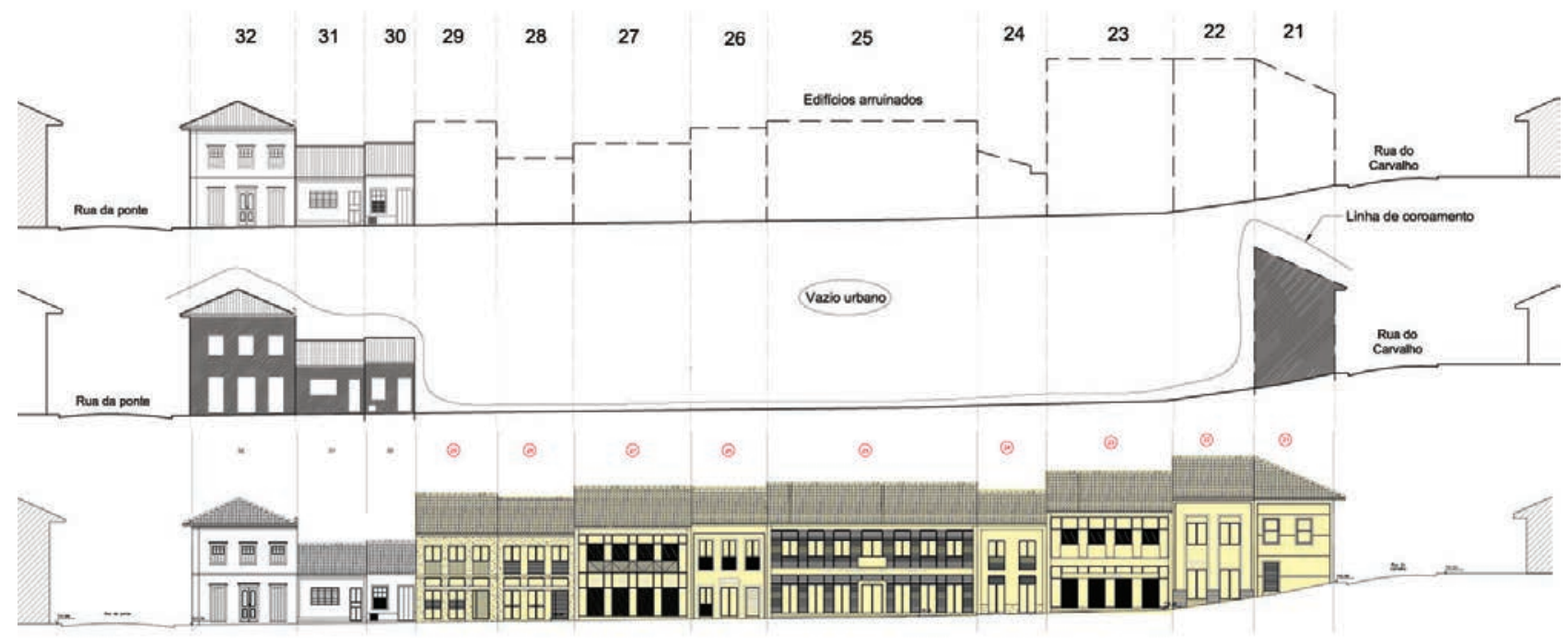

Fonte: Moura (2011).

A praça em estudo tinha como figura principal a igreja Matriz, de grande valor simbólico para a cidade. Ela foi reconstruída logo após o desastre de 2010 por decisão dos Conselhos de Patrimônio que atuam na cidade. O projeto considerou um novo sistema construtivo em estrutura metálica e concreto armado, diverso da taipa de pilão do monumento anterior e o aproveitamento de alguns elementos da antiga igreja como testemunho do ocorrido.

Para o casario ao seu redor, adotamos uma solução diferente, procurando resgatar a unidade visual que se encontrava parcial, sem reconstruir o que foi perdido.

Não se pretendeu, no entanto, propor o preenchimento dos vazios com um novo bloco uniforme e monocromático de casas, na tentativa de se ter uma intervenção de caráter neutro, com novos materiais e modenatura simplificada. Tal postura poderia levar à elaboração de um "pastiche neutro".

Outra opção de preenchimento dessas lacunas, que também não foi adotada aqui, seria aquela que proporia o contraste para afirmar uma novidade, onde o pano de fundo do ambiente antigo estaria conferindo historicidade aos edifícios modernos.

A solução por fim encontrada propôs a construção de novos edifícios com o emprego de materiais contemporâneos, formas novas e criativas, cuja concepção arquitetônica parte da mimese da preexistência, buscando ambientar os novos edifícios ao contexto urbano existente sem usar o recurso da cópia e nem o contraste, tomando o cuidado para que a harmonia e o ritmo estético não fossem rompidos (Figuras 3 a 6 ).

Nesta linha de intervenção, mais importante do que o edifício físico era a ideia por trás dele, o seu conceito artístico. A proposta de intervenção neste ambiente deveria lidar com a restauração da ambiência do local, requalificando a área desta praça.

A intenção final da intervenção projetual sobre a Praça Dr. Oswaldo Cruz foi permitir que a praça, após o restabelecimento de sua unidade plena, despertasse nos observadores das mais diversas sensibilidades artísticas, a sensação de uma harmonia estética, apesar das diferentes épocas em que foram erguidas as edificações neste ambiente urbano.

Além do preenchimento das lacunas existentes, a proposta de requalificação da praça se estendeu também para a área urbana, com intervenção no sistema viário, padronização de mobiliário urbano e iluminação (Figura 7). 
Figura 7 - Proposta de intervenção urbana na praça Dr. Oswaldo Cruz.

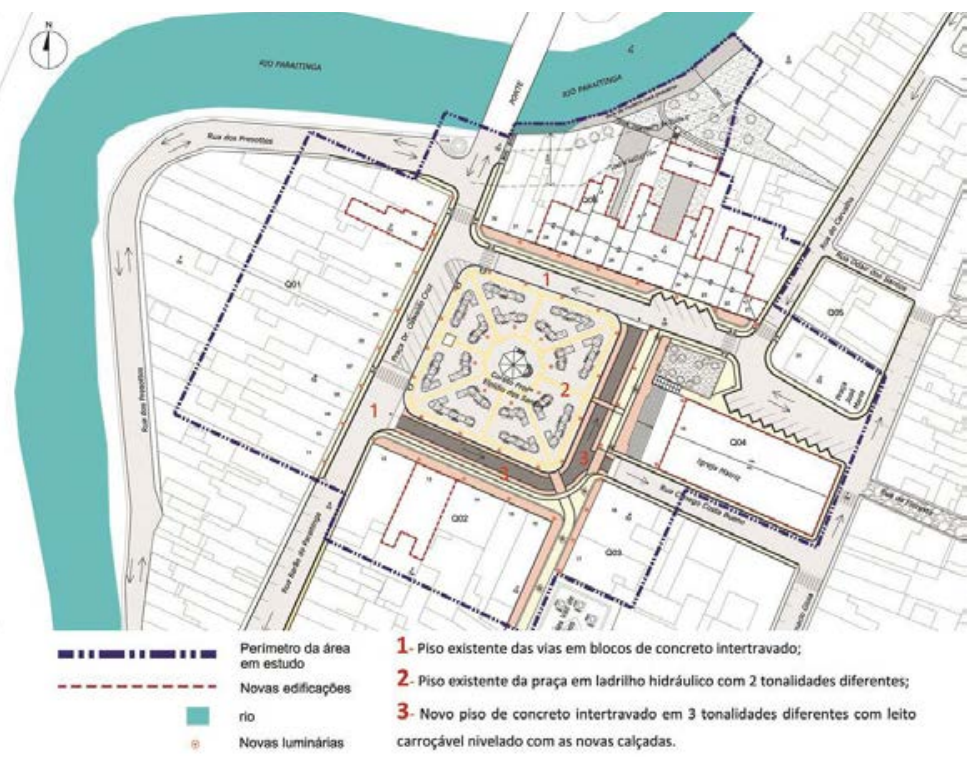

Fonte: Moura (2011).

Os equipamentos urbanos e edifícios a serem introduzidos no centro histórico buscariam melhorar o habitat urbano, de forma a salvaguardar o patrimônio histórico arquitetônico da praça (Figura 8).

Figura 8 - Cortes transversais e longitudinais na praça mostrando o gabarito das edificações e as novas luminárias propostas (em vermelho).

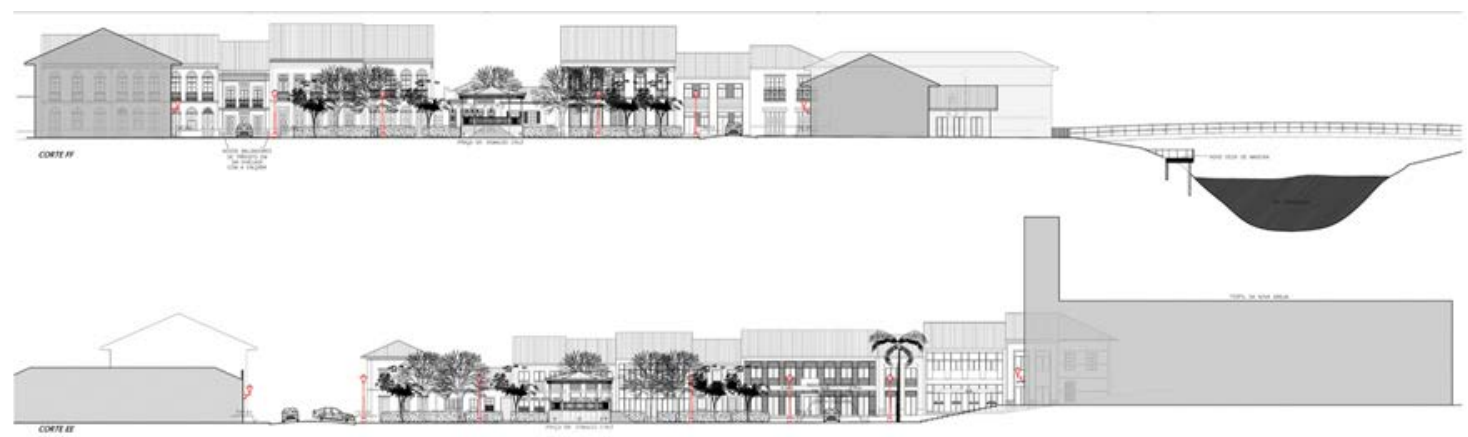

Fonte: Moura (2011).

O ambiente contemporâneo que se pretendeu criar contou com arquitetura e mobiliário urbano contemporâneos, que utilizaram métodos construtivos atuais e que dialogaram com equilíbrio e harmonia com o ambiente histórico. Seguindo um dos métodos da Carta de Veneza, de 1964 (IPHAN, 1995, p. 111), os novos elementos se distinguiram dos elementos originais, encontrados principalmente nos edifícios tradicionais, e revelaram sua época, a fim de que a restauração do ambiente urbano não falsificasse o documento de arte ou a história.

Esta proposta de restauração do tecido urbano apresentou uma solução de como eliminar a tensão visual existente hoje e como resgatar a harmonia da paisagem tradicional da cidade, devolvendo à população o cenário que Ihes é tão familiar e ao mesmo tempo respeitando o curso da história.

\section{REFERÊNCIAS}

IPHAN. Carta de Veneza. In: Cartas Patrimoniais. Brasília: IPHAN, 1995, p. 107-114. .

MOURA, Fernanda Vierno de. São Luiz do Paraitinga: Preservação do centro histórico e intervenção na Praça Dr. Oswaldo Cruz. Trabalho Final desenvolvido no Mestrado Profissional em Conservação e Restauração de Monumentos e Núcleos Históricos da UFBA. Salvador: MP-CECRE UFBA, 2011.

NOTA DO EDITOR (*) O conteúdo do artigo e as imagens nele publicadas são de responsabilidade do(s) autor(es). 


\title{
PROJETO DE RESTAURACĨ̃O DA CASA-GRANDE DA FAZENDA CACHOEIRA DO TAEPE: O EDIFICIO E A UNIDADE AGROPASTORIL.
}

\author{
MURARO, CARMEN LUCIA \\ Arquiteta, Mestre, IPHAN, e-mail: carmenmuraro@yahoo.com.br \\ Trabalho Final desenvolvido no Mestrado Profissional em Conservação e Restauração de Monumentos e Núcleos Históricos. \\ Orientadora: Mariely Cabral de Santana
}

\section{RESUMO EXPANDIDO}

A Fazenda Cachoeira do Taepe, localizada no agreste setentrional de Pernambuco, foi estabelecida, provavelmente, por doação de terra - em regime de sesmaria durante o século XVIII - a integrantes da família Arruda, gente portuguesa atraída, na política de ocupação colonial do Brasil, para a pecuária. (MELLO, 1996).

No século XX, essa atividade foi diversificada com o cultivo e beneficiamento do algodão. Esses afazeres produtivos são percebidos pela permanência, da casa-grande - morada do proprietário da Fazenda e sede do empreendimento rural - do açude, curral, cochos para alimentação do gado e de antigo depósito de algodão. (Figura 1)

Figura 1 - Mapa de localização da casa-grande da Fazenda Cachoeira do Taepe, município de Surubim, agreste pernambucano.

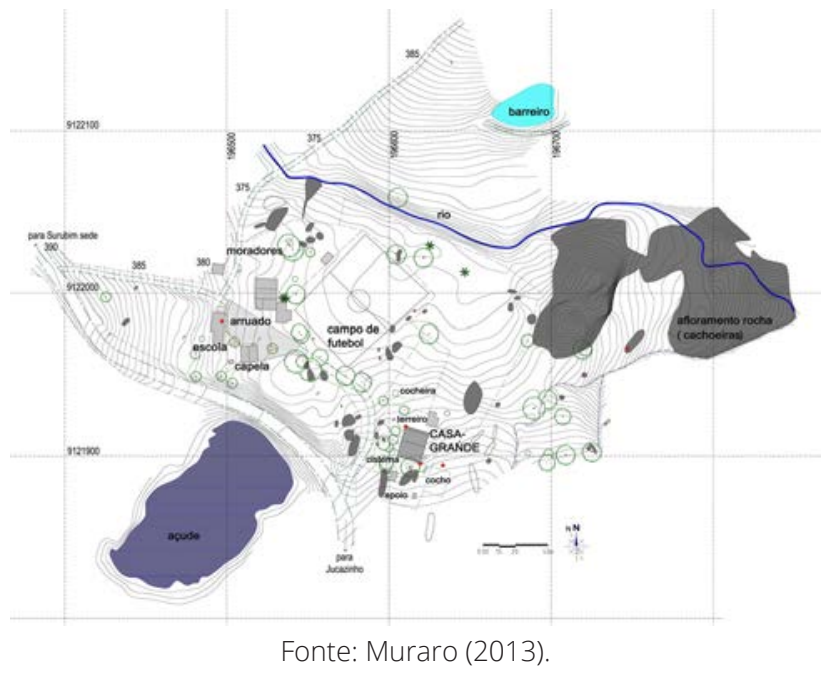

A casa-grande, supostamente instalada desde os primórdios da Fazenda de Taepe, foi construída conforme Vasconcellos (1979) e Weimer (2005) - dentro da tradição do norte de Portugal no que se refere ao embasamento (de pedra argamassada com barro) empregado para nivelar a meia encosta que recebeu a morada erguida em estrutura autônoma (autoportante) de madeira e vedações de pau a pique barreadas em taipa de mão, ou de sopapo. (Figuras 2 e 3)

Figura 2 - Casa-grande da Fazenda Cachoeira do Taepe - fachadas Nordeste (acesso) e Noroeste.

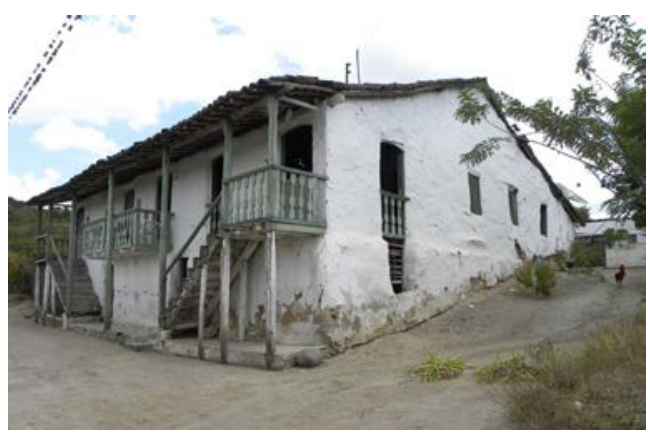

Fonte: Muraro (2013)
Figura 3 - Casa-grande da Fazenda Cachoeira do Taepe - fachadas Nordeste (acesso) e Sudeste.

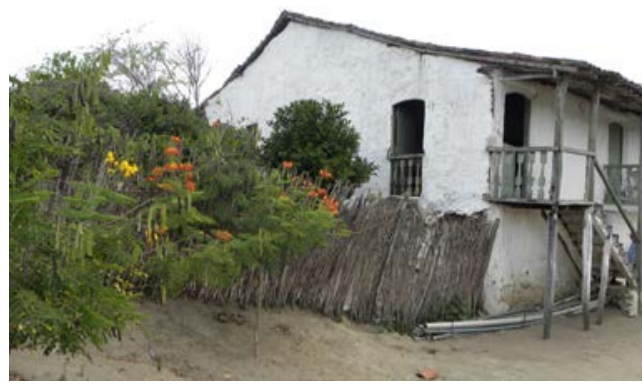

Fonte: Muraro (2013) 
Resumidamente o trabalho, desenvolvido entre 2012 e 2013 para o MP-CECRE (MURARO, 2013), pretendeu a preservação desta unidade rural, elaborada em duas perspectivas: a primeira, voltada para a restauração da casa-grande (tombada pelo Instituto do Patrimônio Histórico e Artístico Nacional - Processo 1.038-T80, Livro Histórico, fls. 84; Inscrição 487 de 27/02/1981). A segunda abordagem vinculada ao processo de restauração procurou identificar e propor estímulos às potencialidades da Fazenda: a saber, alternativas culturais e econômicas que explorem a capacidade desta unidade rural no que se refere a sustentabilidade.

Para enfrentar o desafio de propor a restauração do edifício histórico foi aprofundado o conhecimento do bem por meio da execução de atividades técnicas que abrangeram levantamentos planialtimétrico, cadastral e fotográfico, contextualização histórica, geomorfológica e ambiental, análise do sistema construtivo da casa-grande (reconhecimento por arquitetura comparada e estudos anteriores, dos materiais e técnicas tradicionais empregados), morfologia arquitetônica, mapa de danos e análise do estado de conservação. (RAINVILLE, 1880). O processamento dos dados possibilitou a efetivação de diagnóstico conclusivo. (MELO NETO, MURARO, 2005) (Figuras 4 e 5)

Figura 4 - Perspectiva isométrica da grade estrutural (gaiola) da casa-grande da Fazenda Cachoeira do Taepe (elaborada com base no levantamento cadastral planialtimétrico).

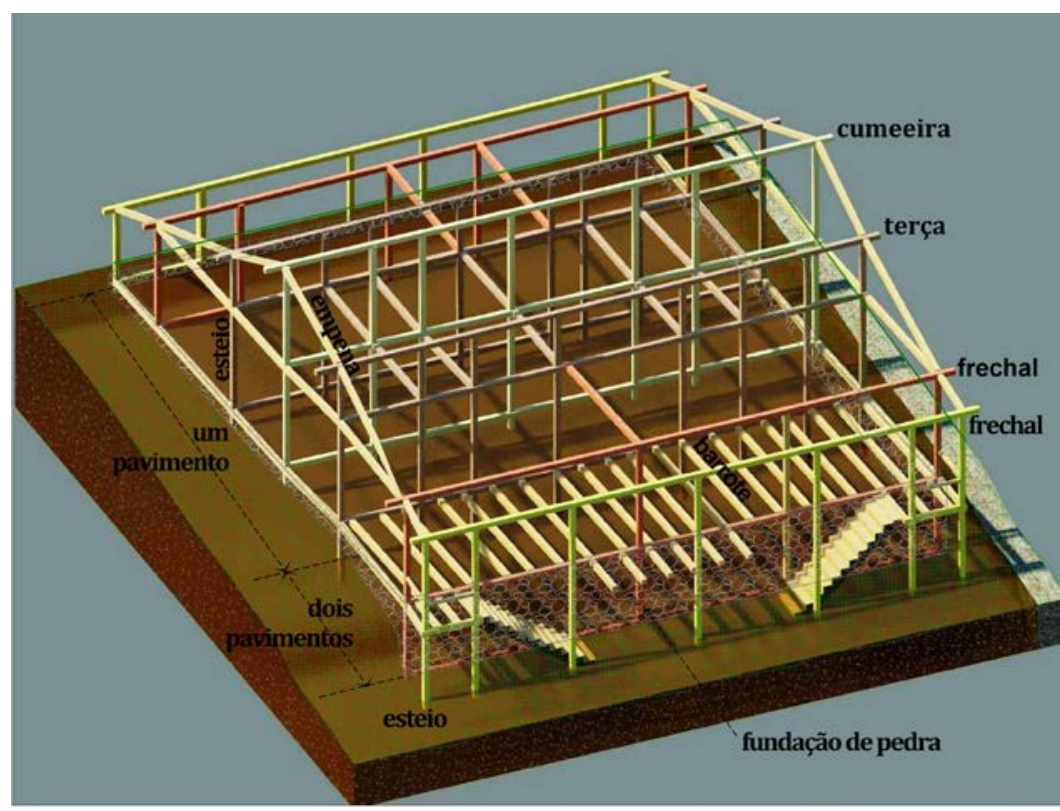

Fonte: Muraro (2013)

Figura 5 - Fachada Noroeste (lateral direita) - registro da estrutura de madeira (gaiola estrutural) sobre embasamento de pedra. Observar cadastro do detalhe construtivo da vedação de pau a pique barreada em taipa de mão, elaborado a partir de janela de prospecção no revestimento.

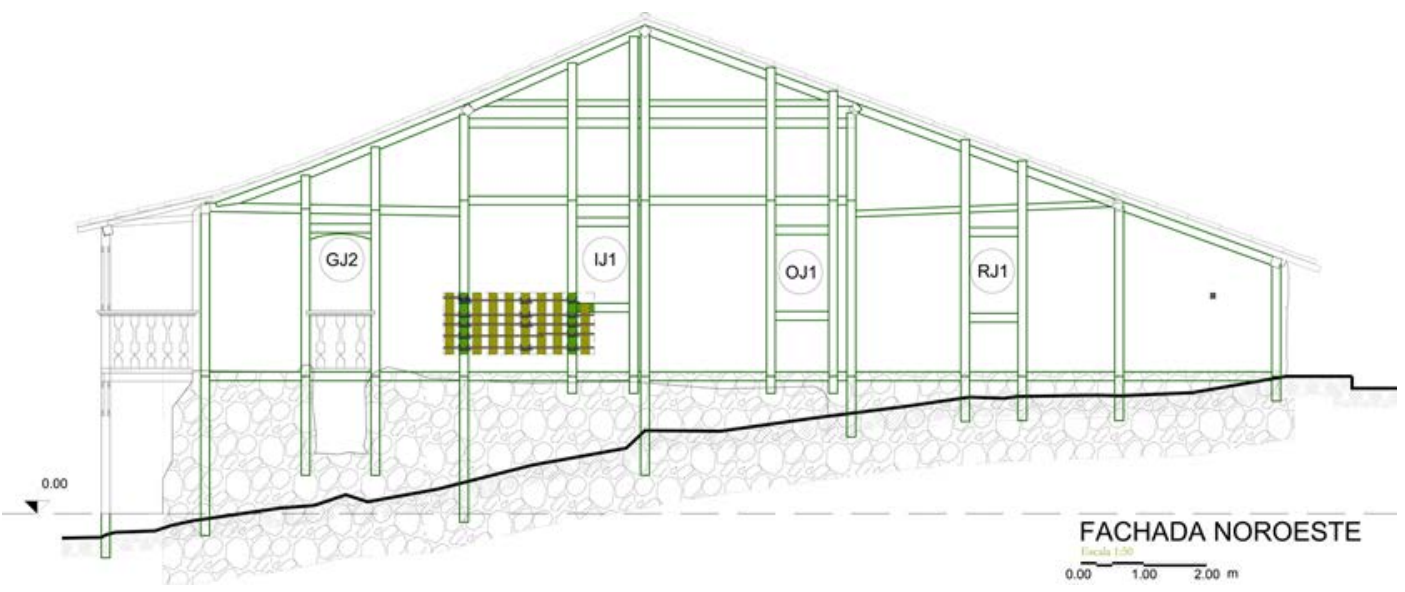

Fonte: Muraro (2013). 
As premissas que nortearam o desenvolvimento projetual se resumem em:

1. A significância cultural da casa de morada e do ambiente circundante é evidência indissociável à Fazenda Cachoeira do Taepe. Sob este aspecto deve-se reiterar que a casa de morada é portadora - no lugar onde está (semiárido pernambucano) e não em outro - de atributos que lhe garantem o mérito da preservação. (MELO NETO, MURARO, 2005)

2. O uso residencial ao longo do tempo é atributo primordial relacionado à imagem do edifício, exemplar da arquitetura rural colonial e as atividades agrícolas que permanecem na Fazenda garantem ao lugar o cenário peculiar que se incorpora, envolve e dá significado à própria casa-grande. (LEMOS, 1989)

3. O conjunto de ações que integra o Projeto de Restauração foi estruturado com base na comprovada interdependência entre agentes e causas de danos conforme o diagnóstico realizado. (SANTIAGO, 2001)

4. Os materiais novos a empregar na restauração deverão ser compatíveis com os componentes do sistema originário. Conforme Isabel Kanan (2008) estudou para argamassas, adotou-se o entendimento de que são substâncias compatíveis as que conciliam propriedades físico-químicas e estéticas sem necessariamente serem as mesmas.

5. Tendo por base reflexões de Brandi (2004), o projeto considerou a maior permanência possível dos materiais originários e das técnicas construtivas então empregadas sem desprezar os recursos contemporâneos, desde que objetivem a ampliação da permanência do bem e estejam comprometidos com a mínima interferência na leitura do objeto cultural enquanto documento.

O projeto de restauração foi elaborado sob quatro enfoques: da investigação complementar (os resultados de 2012 indicaram necessidade de aprofundar o diagnóstico das condições peculiares e diversificadas então encontradas), da consolidação estrutural, da conservação e da requalificação do entorno. As propostas atuaram sobre os materiais e o sistema construtivo, de forma associada, como resposta às causas dos danos (para eliminá-las ou controlá-las) e estabilizar fisicamente o imóvel.

Ainvestigação arquitetônica prevê, entre os procedimentos, aplicação de malha virtual e prospecção controlada sobre fundações, alvenarias de pedra e pau a pique, pisos, argamassas, cobertas, esquadrias. É indicado o reconhecimento de sistema de drenagem, solo natural e condições das atividades desempenhadas na circunvizinhança da casa-grande. (Figura 6)

Figura 6 - Fachada Noroeste (lateral direita) - Aplicação de malha virtual sobre o levantamento cadastral para definição dos pontos de pesquisa por prospecção arquitetônica (Projeto de restauração - investigação).

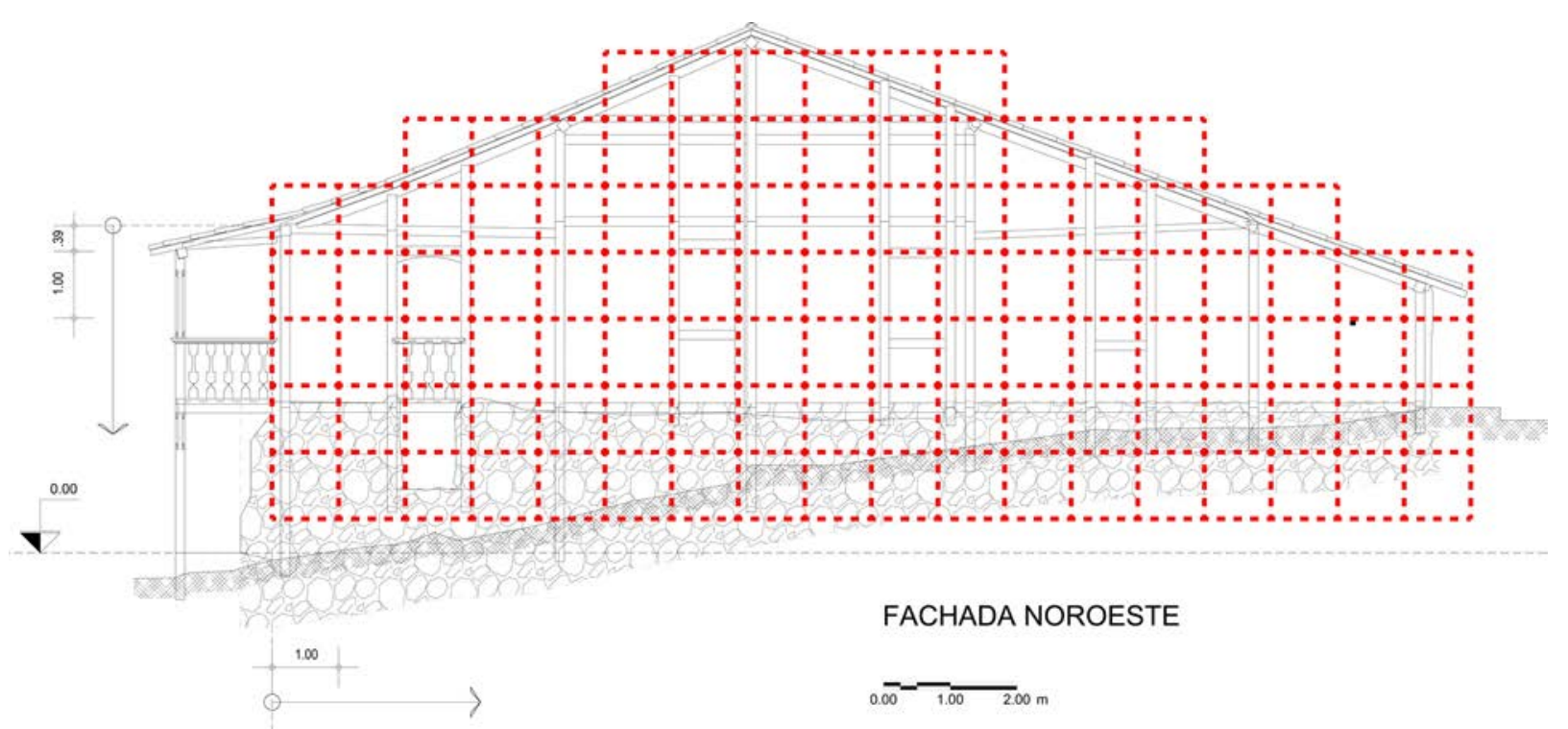

Fonte: Muraro (2013). 
O segundo foco refere-se à consolidação estrutural, ações que atuam, de forma preventiva ou curativa, sobre materiais (in natura ou artificiais) seja enquanto substância constituinte seja enquanto função desempenhada no sistema construtivo. (Figuras 7-8)

Figura 7 - Detalhe construtivo de recomposição de vigas de madeira - ligação das partes com chapa metálica embutida e consolidada à madeira com resina epóxi. Sistema WER (Wood Epoxy Reinforcement) (Projeto de restauração - consolidação).
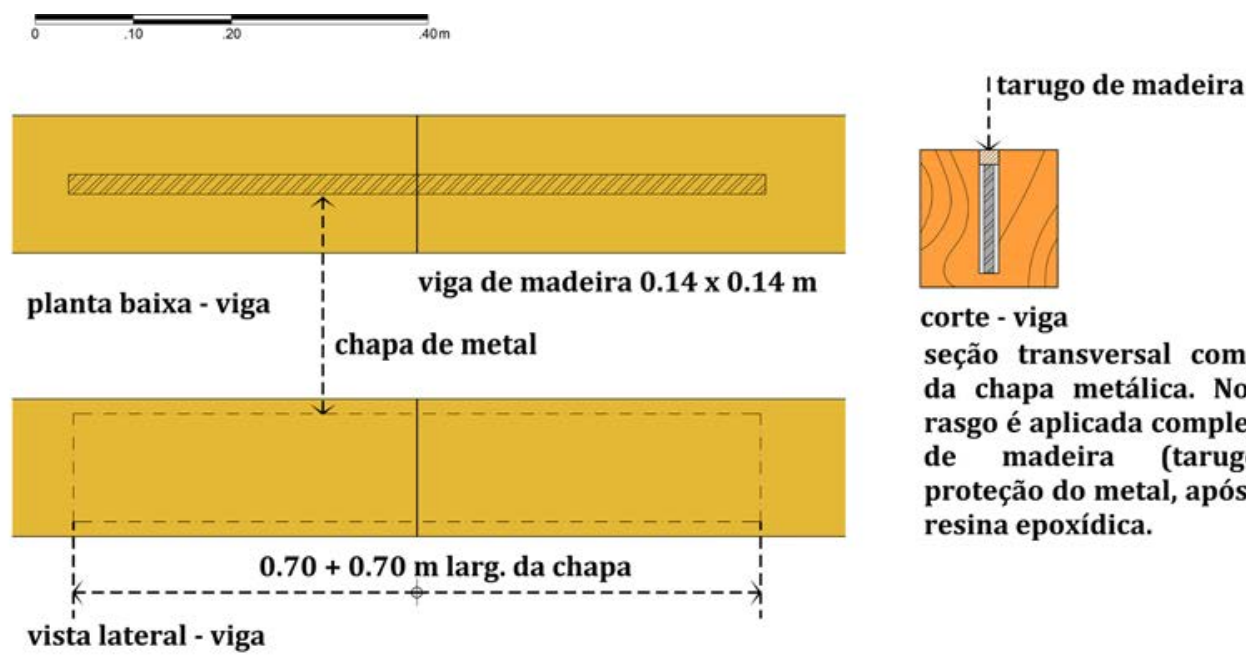

corte - viga

seção transversal com inserção da chapa metálica. No topo do rasgo é aplicada complementação de madeira (tarugo) para proteção do metal, após a cura da resina epoxídica.

Fonte: Muraro (2013)

Figura 8 - Detalhe construtivo da viga box projetada para apoio da coberta da casa-grande - dois perfis soldados, apoio para os caibros das salas. (Projeto de restauração - consolidação).

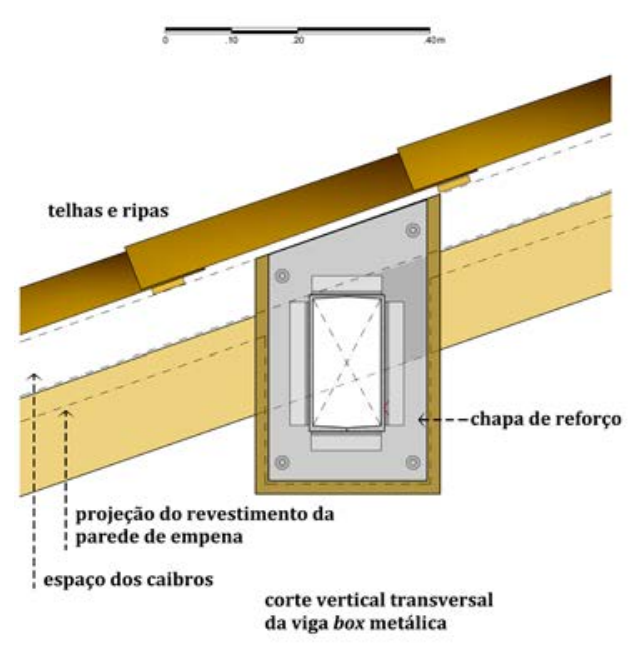

da viga box metálica

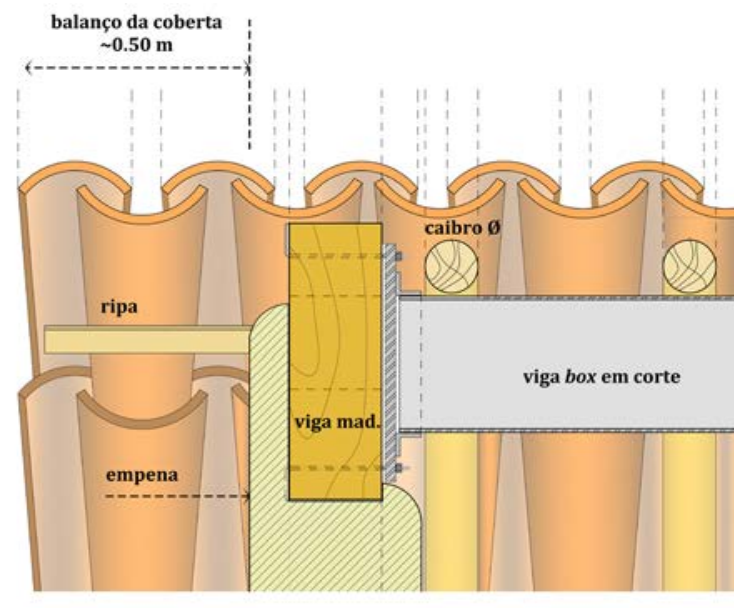

corte longitudinal da viga box metálica

Fonte: Muraro (2013)

No sentido de conservar materiais, espaços internos e ambiência da casa-grande foram desenvolvidas propostas técnicas, mantidos os focos sobre ações preventivas ou curativas que visaram beneficiar materiais construtivos constituintes de paredes, esquadrias e bens integrados, pisos, coberta, instalações bem como os ambientes molhados (cozinha e banheiros), os quais foram objetos de projetos arquitetônicos específicos.

O entorno imediato da casa-grande, considerado parte integrante e constituinte da unidade de morada em estudo, recebeu estudos de requalificação que pretenderam fazer frente às demandas contemporâneas (século XXI) somadas à possibilidade de inserção de novos usos no lugar sem, no entanto, alterar a vida doméstica consolidada. Este âmbito teve por função conectar a restauração da casa-grande ao esforço de garantir sustentabilidade à unidade rural. 
No plano pessoal, a experiência acadêmica adquirida ao longo de dezesseis meses promoveu reflexões e novos desafios. Um deles é o de tornar o referido projeto de restauração acessível a grupo mais amplo da sociedade, garantindo assim o sentido da pesquisa e da produção acadêmica.

\section{REFERÊNCIAS}

BRANDI, Cesare. Teoria da Restauração. Cotia: Ateliê Editorial, 2004.

KANAN. Maria Isabel. Manual de conservação e intervenção em argamassas e revestimentos à base de cal. Brasília: IPHAN, Programa Monumenta, 2008.

LEMOS, Carlos A. C. História da Casa Brasileira. São Paulo: Contexto, 1989.

MELLO, José Antônio Gonsalves de. Três Roteiros de Penetração do Território Pernambucano (1738 e 1802). Monografia nº 3. Instituto de Ciências do Homem. Recife: Imprensa Universitária, 1966.

MELLO NETO, Ulysses Pernambucano de; MURARO, Carmen Lucia; MELO. O Futuro do Passado. In: MELLO NETO, Ulysses Pernambucano de; MURARO, Carmen Lucia; MELO, Roberto Salomão do Amaral e. Coleção Engenho Poço Comprido. Recife: Programa de Desenvolvimento Sustentável da Zona da Mata de Pernambuco (Promata), 2005, v. 2.

MURARO, Carmen Lucia. Projeto de restauração da Casa-Grande da Fazenda Cachoeira do Taepe: o edifício e a unidade agropastoril. Trabalho Final desenvolvido no Mestrado Profissional em Conservação e Restauração de Monumentos e Núcleos Históricos da UFBA. Salvador: MP-CECRE UFBA, 2013.

RAINVILLE, César de. O Vignola Brasileiro. Novo Manual Prático do Engenheiro, Architecto, Pedreiro, Carpinteiro, Marceneiro e Serralheiro. Rio de Janeiro: Eduardo \& Henrique Laemmert, 1880.

SANTIAGO, Cybèle Celestino. O Solo como Material de Construção. Salvador: EDUFBA, 2001

VASCONCELLOS, Sylvio de. Arquitetura no Brasil: Sistemas Construtivos. Belo Horizonte: EA UFMG, 1979.

WEIMER, Günter. Arquitetura Popular Brasileira. São Paulo: Martins Fontes, 2005.

NOTA DO EDITOR (*) O conteúdo do artigo e as imagens nele publicadas são de responsabilidade do(s) autor(es). 


\title{
PROJETO DE RESTAURAÇ̃̃O PARA O CINE TEATRO JANDAIA, EM SALVADOR
}

\author{
AMORIM, MLEENA FRAGA DE \\ Arquiteta, Mestre, professora FAAT Faculdades, coordenadora Estúdio Par, e-mail: milenafraga.a@gmail.com \\ Trabalho Final desenvolvido no Mestrado Profissional em Conservação e Restauração de Monumentos e Núcleos Históricos. \\ Orientador: Rodrigo Espinha Baeta
}

\section{RESUMO EXPANDIDO}

O trabalho final desenvolvido na segunda da edição do MP-CECRE (AMORIM, 2013) prevê a restauração de uma edificação monumental abandonada há duas décadas, em avançado processo de degradação, inserida num complexo contexto urbano de degradação física e social, do qual fazem parte as áreas limítrofes do Centro Histórico de Salvador - o Cine Teatro Jandaia (Figura 1).

Figura 1- Vista do edifício e da Rua José Joaquim Seabra a partir do Centro Histórico.

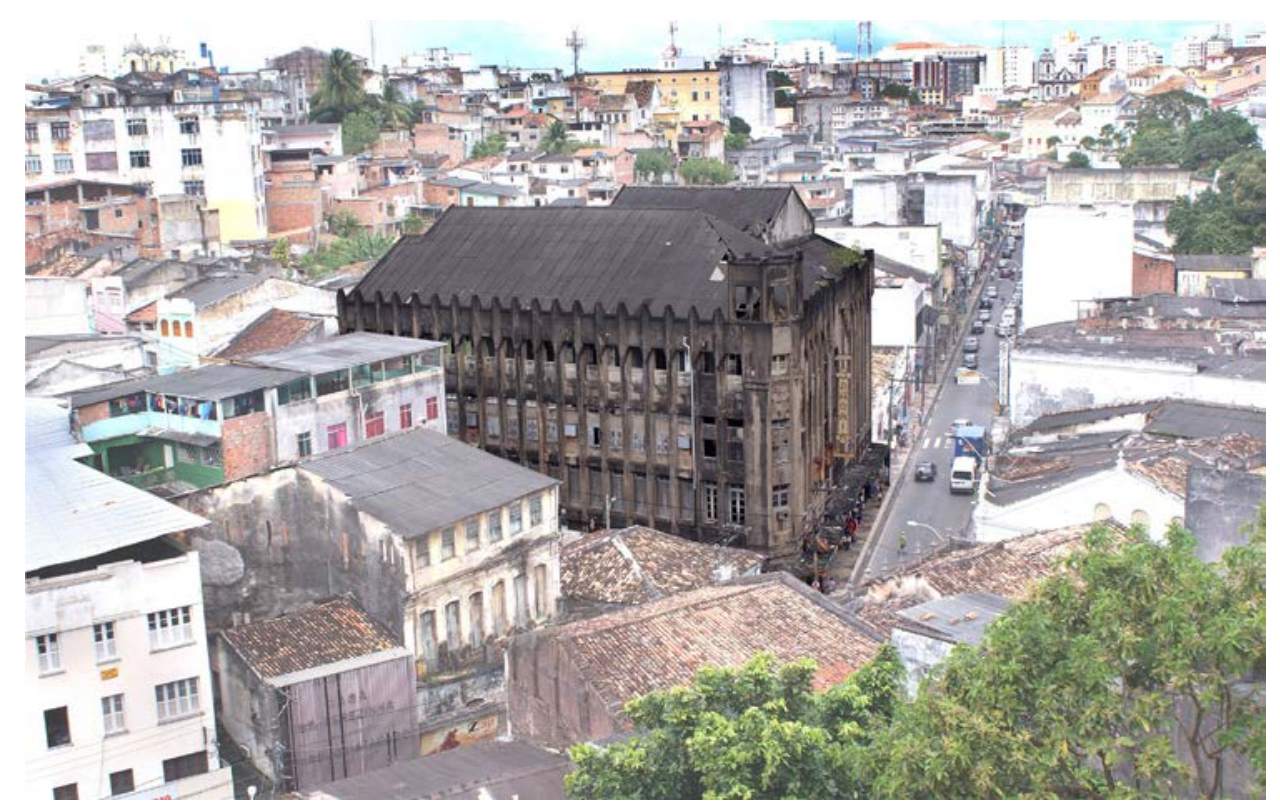

Fonte: Fotografia de Roberto Nascimento, 2008

O Cine Teatro Jandaia foi construído no início dos anos 1930, numa época em que diversas ruas do centro da cidade passavam por grandes reformas de higienização e modernização. O clima de modernização não se limitava ao contexto urbano, sendo a própria tipologia "cine teatro" um símbolo do avanço tecnológico com a chegada do cinema - e entre as décadas de 1930 e 1950 foi um dos principais equipamentos de cultura e lazer no país.

A arquitetura dos edifícios culturais da época, sobretudo os cinemas, está estritamente ligada ao "estilo" art déco, pelo que traz de representação de luxo e modernidade. É comum encontrar temas diversos numa mesma edificação, como acontece no Cine Teatro Jandaia. Sua fachada é extremamente verticalizada através de elementos chamados "goticizantes" - marcos verticais que aumentam a percepção da altura dos edifícios e atraem o olhar para o topo (Figura 2). As fachadas são revestidas com argamassa de pó de pedra, contrastando com o colorido vitral que marca a fachada principal e o eixo central do edifício, numa simetria forçada. Internamente é marcante a presença de frisos e adornos em gesso com motivos 
geométricos, de folhas e figuras femininas, além de uma enorme rosácea em gesso presente no forro em estuque (Figura 3). Haviam pinturas decorativas, conforme relatos e fotos antigas, porém todas foram cobertas nas diversas reformas e reparos.

Figura 2 - Panorama do Cine Teatro Jandaia. Esquina da Rua José Joaquim Seabra com a Rua do Alvo.

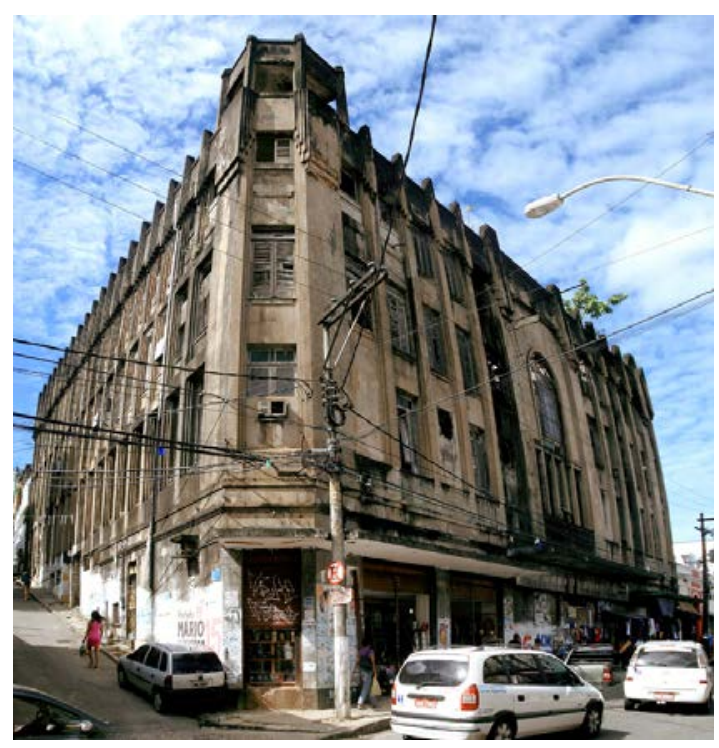

Fonte: Amorim (2013)

Figura 3 - Vista da plateia e camarotes a partir do palco.

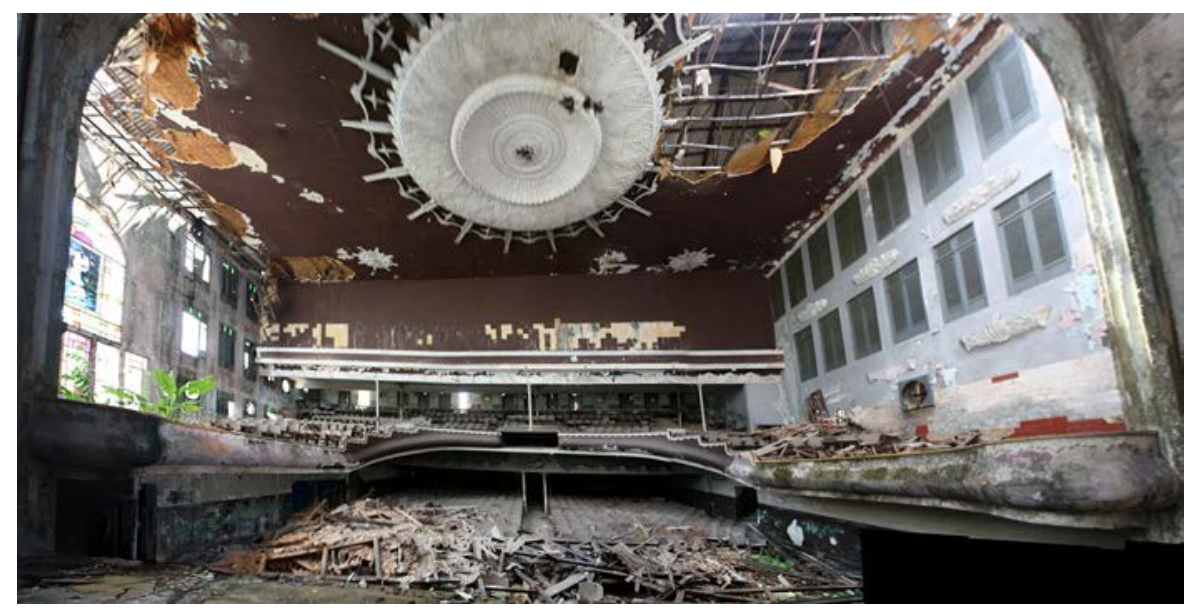

Fonte: Amorim (2013).

Como metodologia adotada para o desenvolvimento da proposta de intervenção, foi feita uma investigação do contexto urbano e social da região do Centro Histórico, e mais especificamente do entorno da Baixa dos Sapateiros. Também foi investigada a arquitetura art déco enquanto manifestação estética moderna, bem como o papel dos cines teatros e seus destinos ao longo do tempo no Brasil. Em seguida foi feito um cuidadoso levantamento cadastral da edificação, utilizando-se de técnicas de fotogrametria digital para o desenho das fachadas, análise física e ambiental e por fim análise das patologias encontradas através de mapeamento de danos, ensaios laboratoriais e elaboração do diagnóstico.

Na escolha do uso e determinação das diretrizes de projeto, a identificação das características fundamentais da edificação foram essenciais. O edifício possui estrutura de palco e plateia com frisas e camarotes que formam um grande vão interno com pé direito muito alto e grande visibilidade do espaço. Por estas características arquitetônicas tão singulares e rígidas que têm os espaços teatrais, optou-se por manter o uso de teatro e casa de espetáculos, aproveitando assim a citada estrutura. Consideramos que qualquer outro uso que não aproveitasse ou modificasse esta configuração estaria destruindo a edificação nas suas características fundamentais e seria entendido como uma transformação em novo espaço sem relação com o anterior, e não uma restauração. 
Existem espaços onde as intervenções deveriam ser muito mais de conservação, como por exemplo, nas áreas de plateia e boca de cena, no foyer e nas fachadas voltadas para as ruas. Por outro lado, outras áreas já não conservavam traços da arquitetura déco ou não se integravam esteticamente com o inteiro da obra. São espaços completamente transformados, como as lojas do pavimento térreo, ou espaços sem nenhum vestígio do que podem ter sido. Naqueles ambientes que mais conservam a estética da edificação, foi proposta a restauração das partes existentes, no intuito de reconstituir a estética do edifício, sem que isto significasse refazer, por analogias e comparação com fotos, elementos perdidos. As necessárias inserções de equipamentos e estruturas indispensáveis como, por exemplo, instalações de ar condicionado, deveriam ser colocadas de modo a interferirem o mínimo possível na composição da edificação.

Nos demais ambientes, desintegrados esteticamente do todo, foi possível uma maior liberdade de intervenção, uma vez que não resta o que preservar destes (Figuras 4-5).

Figura 4 - Esquema ilustrativo de setorização do projeto.

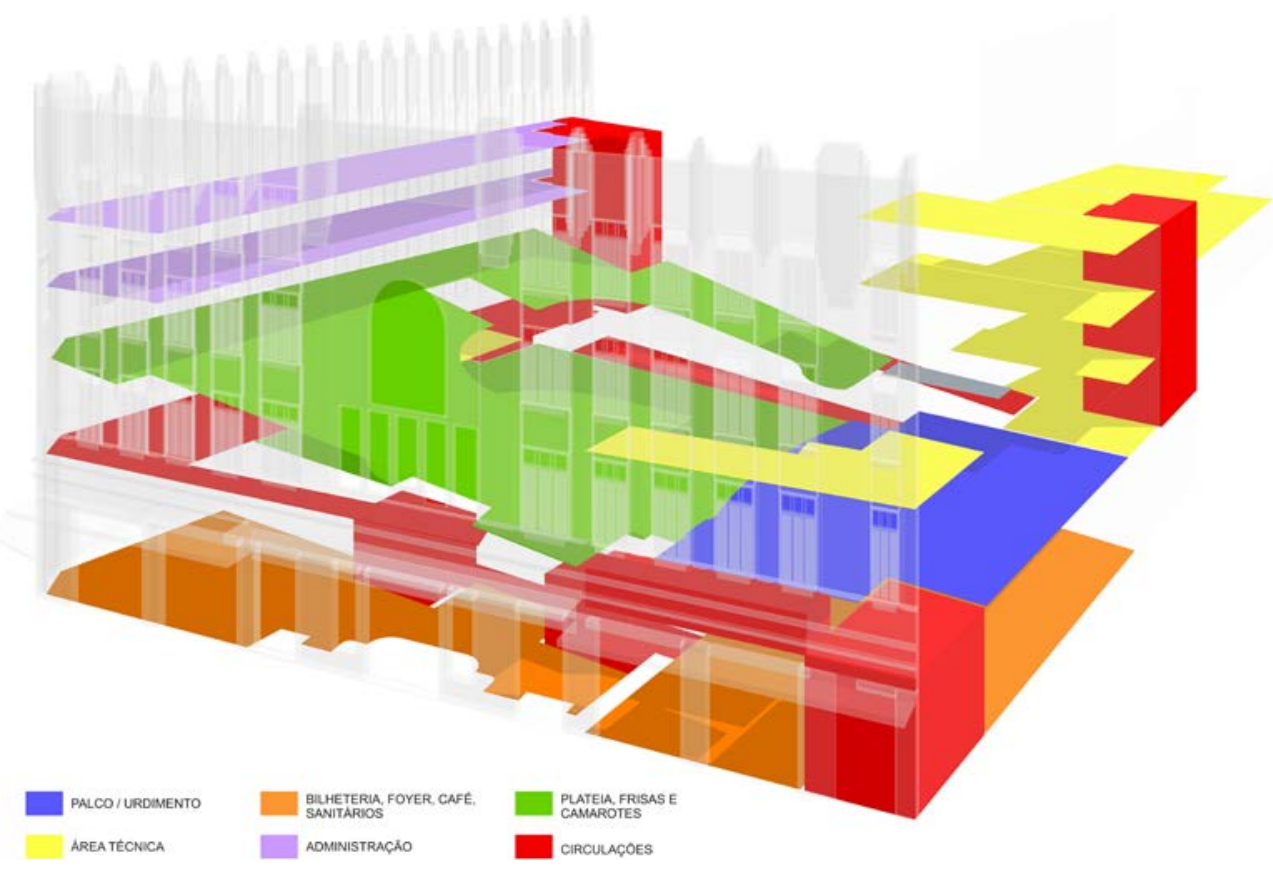

Fonte: Amorim (2013).

Figura 5 - Projeto de restauração e requalificação. Planta baixa do nível da plateia. Acessos pelo foyer original e também por antecâmara proposta.

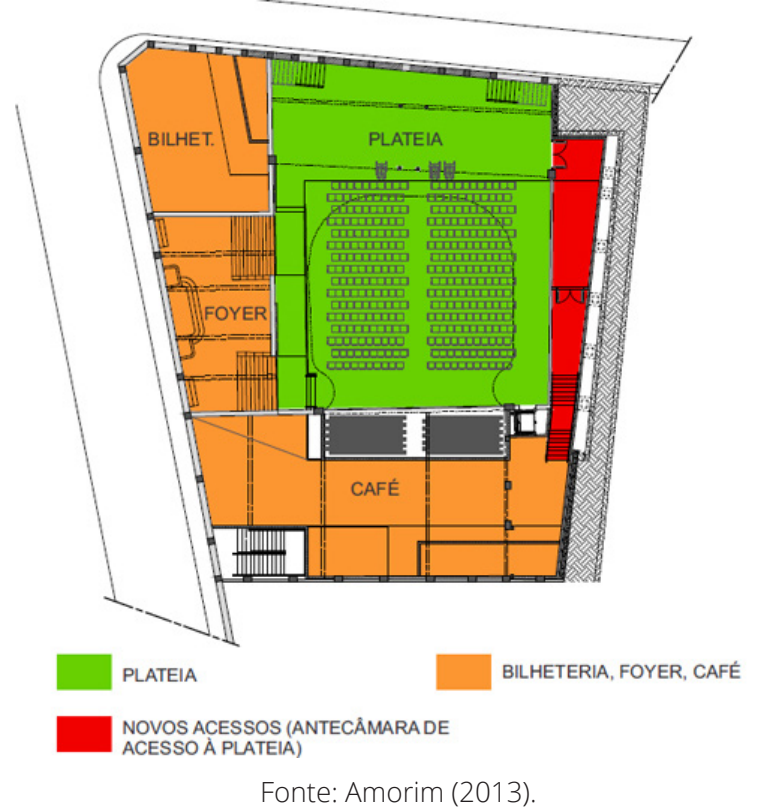


Vale ressaltar que estes se integram com o todo nas suas disposições espaciais, limites de área, sugestões de fluxos, funções e acessos. Estas premissas também foram levadas em consideração ao processo projetual e tomadas como guias. Alterá-las seria alterar de certa forma uma lógica de funcionamento sugerida pela edificação, o que também sairia do âmbito da restauração que se pretende realizar (Figura 6).

Figura 6 - Projeto de restauração e requalificação. Planta baixa do nível dos camarotes.

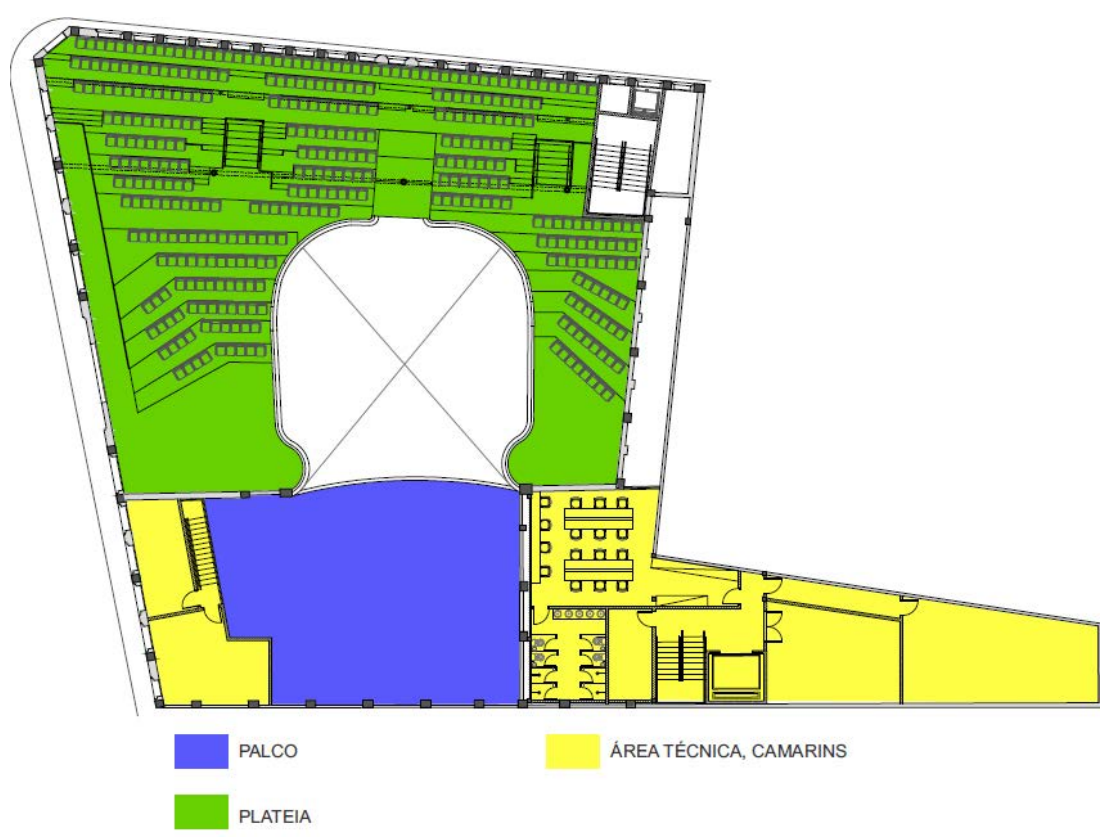

Fonte: Amorim (2013).

Foram pensadas novas aberturas para fazer a comunicação entre ambientes do térreo, antes isolados e independentes, conectando bilheteria e café sem interferir no foyer original, além de novo acesso à plateia por antecâmara. Para isto, aproveitou-se a cota elevada da plateia e foi proposta uma circulação enterrada. Um novo acesso por antecâmara também foi proposto, uma vez que o acesso à plateia originalmente acontecia diretamente pelo foyer. Aproveitou-se a existência de estrutura de pilares no pavimento superior e fez-se a antecâmara entre a parede da plateia existente e esta estrutura, levando em consideração a provável existência de sapatas na fundação (Figura 7).

Figura 7 - Projeto de restauração e requalificação. Secção longitudinal com setorização.

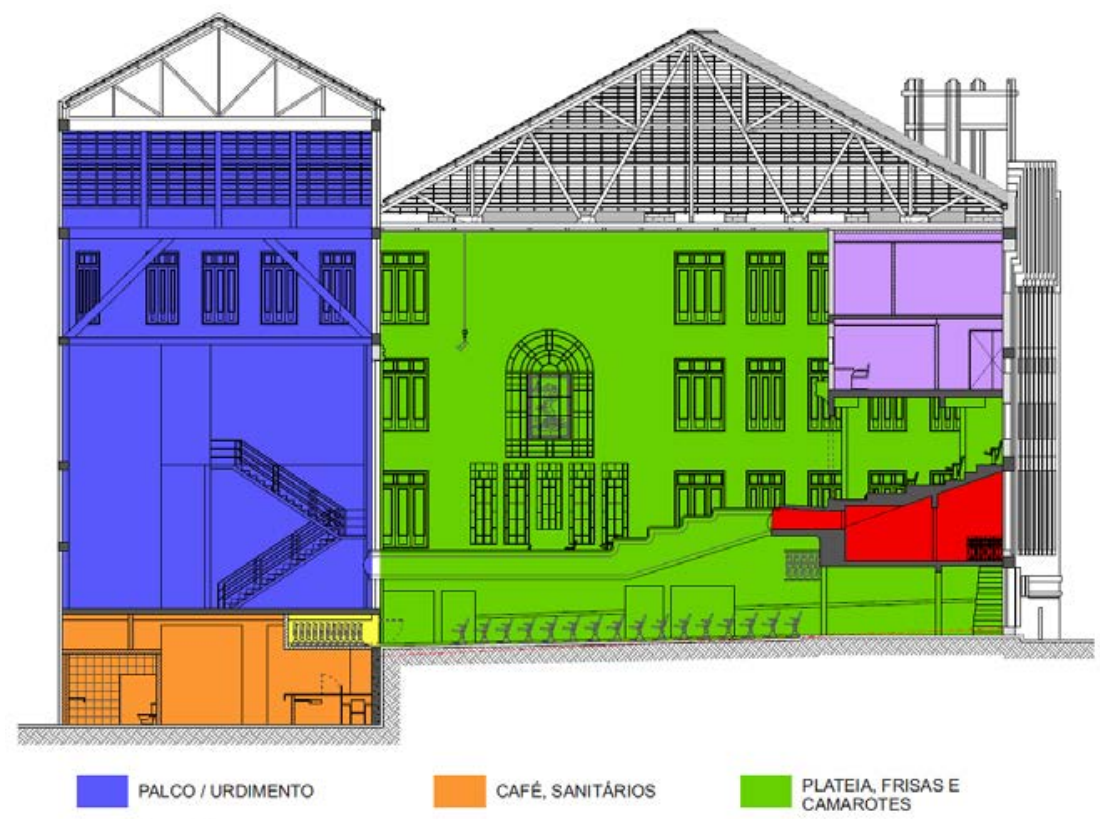

Fonte: Amorim (2013). 
As áreas técnicas como camarins, manutenção e sala de ensaio foram alocadas em um novo volume proposto na área do terraço existente ao lado do palco. Esta área encontra-se na lateral e fundo do terreno, que já possuía acesso direto por uma via lateral e é um dos locais onde consideramos ter maior liberdade de intervenção (Figura 8).

Figura 8 - Projeto de restauração e requalificação. Secção transversal com setorização.

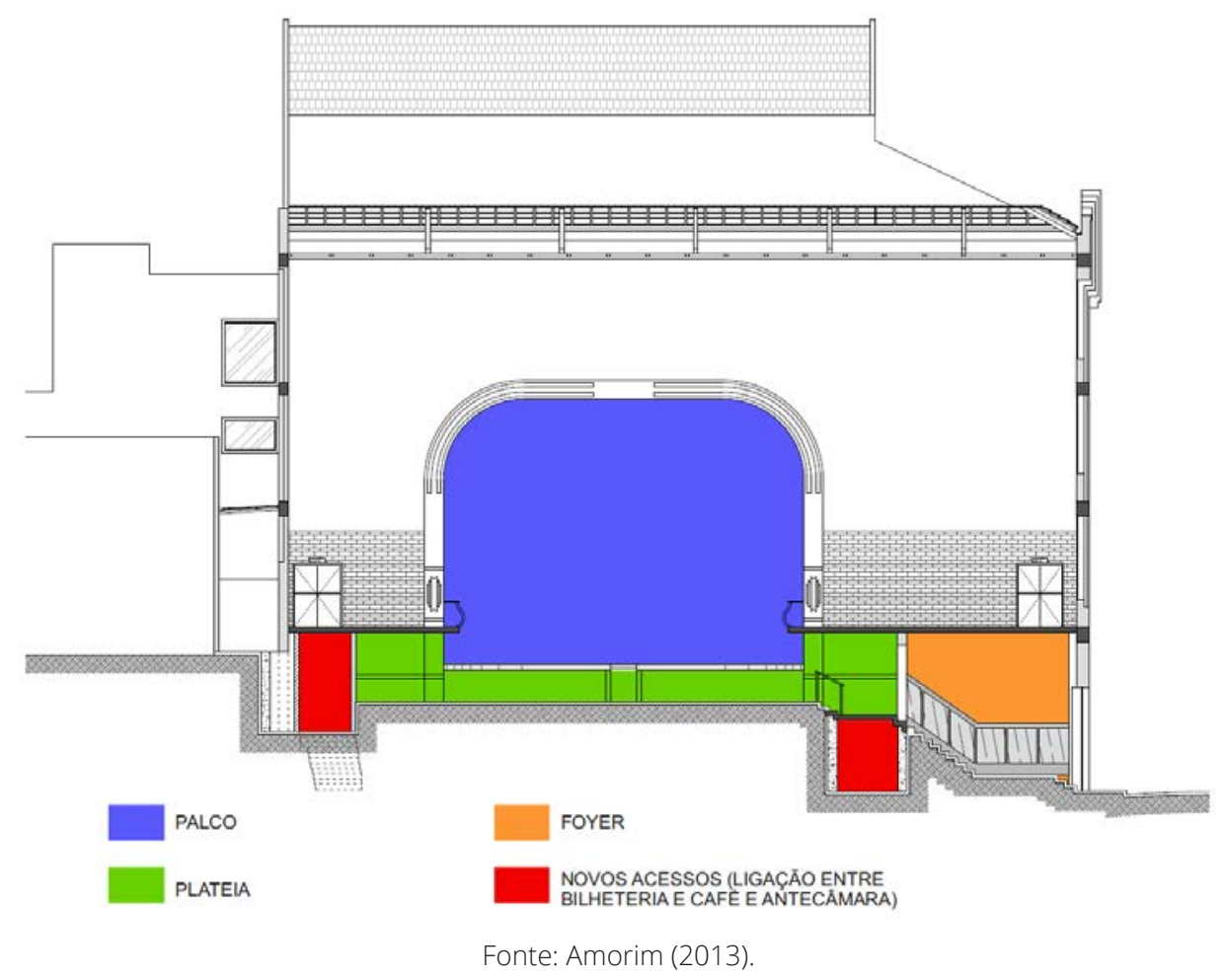

A proposta também contemplou indicação de medidas restaurativas a serem adotadas.

Com o desenvolvimento do trabalho, provamos ser possível a restauração da edificação mantendo de certa forma seu uso original - excluindo a função de cinema - e ter esta restauração como ponto importante numa perspectiva mais abrangente de revalorização do sítio urbano.

\section{REFERÊNCIAS}

AMORIM, Milena Fraga. Projeto de restauração para o Cine Teatro Jandaia, em Salvador. Trabalho Final desenvolvido no Mestrado Profissional em Conservação e Restauração de Monumentos e Núcleos Históricos da UFBA. Salvador: MP-CECRE UFBA, 2013.

NOTA DO EDITOR (*) O conteúdo do artigo e as imagens nele publicadas são de responsabilidade do(s) autor(es). 


\section{RESTAURAĢ̄̃O DO CONVENTO DE SANTA TERESA DE CARMELTTAS DESCALZAS: PROJETO PARA A ESCOLA SUPERIOR DE ARTE, EM COCHABAMBA, BOLÍVIA}

\section{CANDIA BARRIENTOS, ALICIA GABRIELA}

Arquiteta, Mestre, Profissional Autônoma, colabora com a empresa Terysos do Brasil, e-mail: a.gabrielacandiabarrientos@gmail.com Trabalho Final desenvolvido no Mestrado Profissional em Conservação e Restauração de Monumentos e Núcleos Históricos.

Orientador: Nivaldo Vieira de Andrade Junior

Coorientador: Rodrigo Espinha Baeta

Tradução do espanhol para o português e revisão: Rodrigo Espinha Baeta.

\section{RESUMO EXPANDIDO}

O Monastério de Carmelitas Descalzas de Santa Teresa, construído no século XVIII e localizado na cidade de Cochabamba, na Bolívia, pode-se considerar o maior e mais importante conjunto monumental da época colonial da cidade, por seus relevantes méritos em termos históricos, artísticos e arquitetônicos.

Entre estes méritos, destaca-se a inusitada conformação das paredes externas inacabadas da igreja principal dedicada a Santa Teresa, edificadas na segunda metade dos setecentos: paredes laterais polilobuladas, que lembram os contornos internos da Igreja de San Carlo alle Quattro Fontane (1638), em Roma, concebida e edificada por Francesco Borromini (1599-1667). Estes muros pulsantes, caso único na Bolívia e muito raro na América hispânica, acolheriam o interior do templo, mas ficaram inconclusos e acabaram envolvendo a igreja neoclássica atual, edificada posteriormente, em finais do século XVIII.

O Convento de Santa Teresa é uma grande estrutura que ocupa a quase totalidade de um quarteirão da região central do núcleo urbano - um organismo arquitetônico composto por duas igrejas e quatro claustros. Devido à complexidade e à magnitude do aglomerado edilício, mas também em função de uma parte significativa do complexo, que envolve três dos claustros, ser mais recente e menos significativa no que se refere ao desenvolvimento histórico e a continuidade artística do convento, definiu-se intervir apenas na outra metade mais degradada. Este antigo setor do monastério carmelita - de certo modo isolado em relação aos claustros mais novos-, abrange a primeira igreja arruinada, a atual basílica neoclássica envolvida pelas paredes polilobuladas da inacabada igreja barroca, o claustro principal e outras áreas externas. (Figura 1)

Figura 1- Vista aérea do Monastério de Santa Teresa.

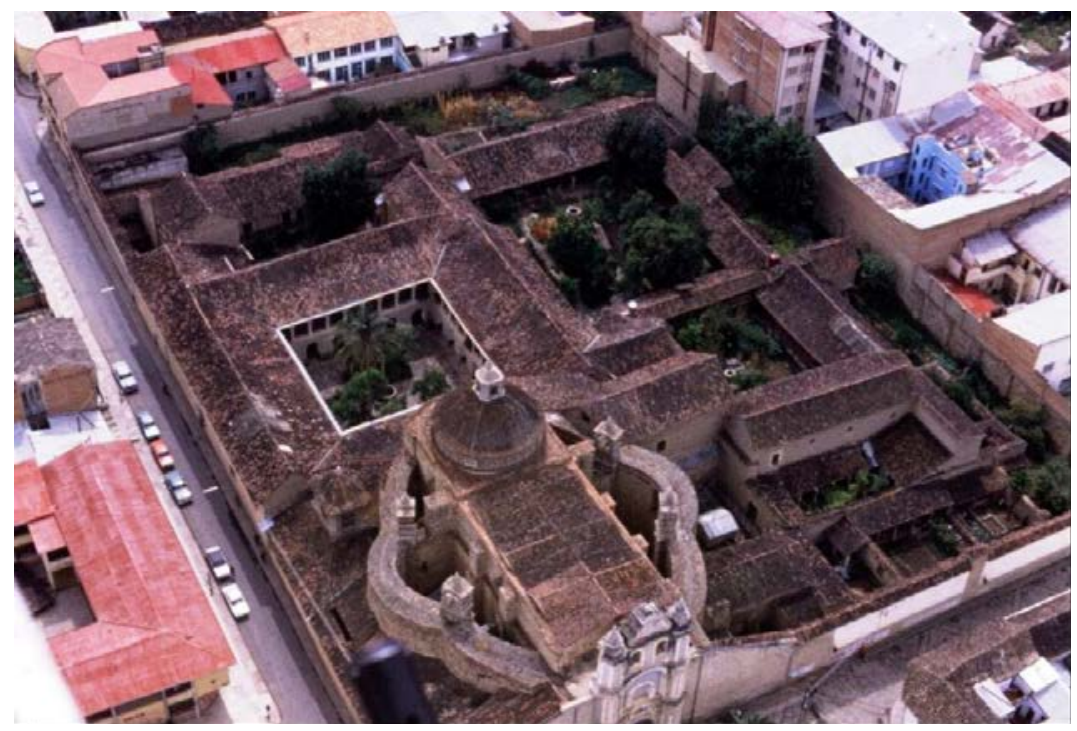

Fonte: Fotografia do Arquiteto Carlos Lavayen, 1980. 
A premissa básica do Trabalho Final desenvolvido para o MP-CECRE (CANDIA BARRIENTOS, 2016) foi a elaboração de um projeto de intervenção arquitetônica para a requalificação das estruturas mais relevante do complexo religioso - com a sua adaptação a dois usos: a Escola Superior de Arte de Cochabamba, e uma melhor adequação ao Museu do Convento que o claustro já acolhia.

Para isso, a partir de uma profunda investigação das informações históricas das etapas construtivas do convento, em conjunto com o levantamento cadastral minucioso das unidades arquitetônicas que compunham o setor, buscou-se encontrar e entender as temporalidades do edifício. Essas informações foram usadas como pressupostos para o desenvolvimento do projeto de restauração: cada elemento arquitetônico foi trabalhado como uma estrutura independente que requeria soluções particulares (a primeira igreja arruinada, a segunda igreja íntegra, as paredes curvilíneas inacabadas dessa segunda igreja mais recente, o claustro, as áreas externas). Não obstante, procurou-se, ao final, conquistar uma absoluta unidade projetiva.

Tentou-se incorporar à diversidade das fases históricas do conjunto, a inserção de elementos contemporâneos. Contudo, evitou-se a inclusão narcisista e dissonante de acrescimentos, mesmo entendendo que os elementos que devem complementar as lacunas no tecido figurativo do monumento não devem cair em uma reconstrução estilística ou em imitações mal sucedidas.

Para alcançar esta tarefa, foram utilizados instrumentos projetuais específicos. Para uma melhor leitura das soluções projetivas, o complexo carmelita foi dividido e classificado em duas áreas principais que determinaram graus de intervenção diversos.

Área de regeneração determinada pelo recorte composto pela igreja mais antiga. Neste organismo arquitetônico, a condição de alto grau de arruinamento, com a perda de paredes externas e de todo o interior, permitia mais liberdade no que tange ao design arquitetônico. Foi também entendido que, do ponto de vista da restauração do complexo arquitetônico, a recomposição contemporânea do espaço fragmentado seria necessário. Para além disso, foi proposta a liberação visual do frontispício da igreja antiga para a rua, já que sua fachada principal estava oculta por um muro que encobria toda a elevação lateral do convento. Finalmente, o espaço recuperado da primeira igreja seria requalificado para conter diversos itens do programa de escola de artes.

Área de Conservação, que consiste a estrutura do claustro e a igreja principal, entendendo-se que este setor possui integridade tanto tipológica como arquitetônica (Figura 2). Por conseguinte, decidiu-se que o andar térreo do claustro seria readaptado aos espaços que deveriam acolher o acervo do museu, enquanto o piso superior serviria para o usufruto da escola de arte. A igreja, por sua vez, deveria preservar sua função litúrgica, sendo promovidas intervenções de conservação e consolidação das estruturas e materiais construtivos.

Figura 2 - Vista Parcial do Claustro do Monastério de Santa Teresa.

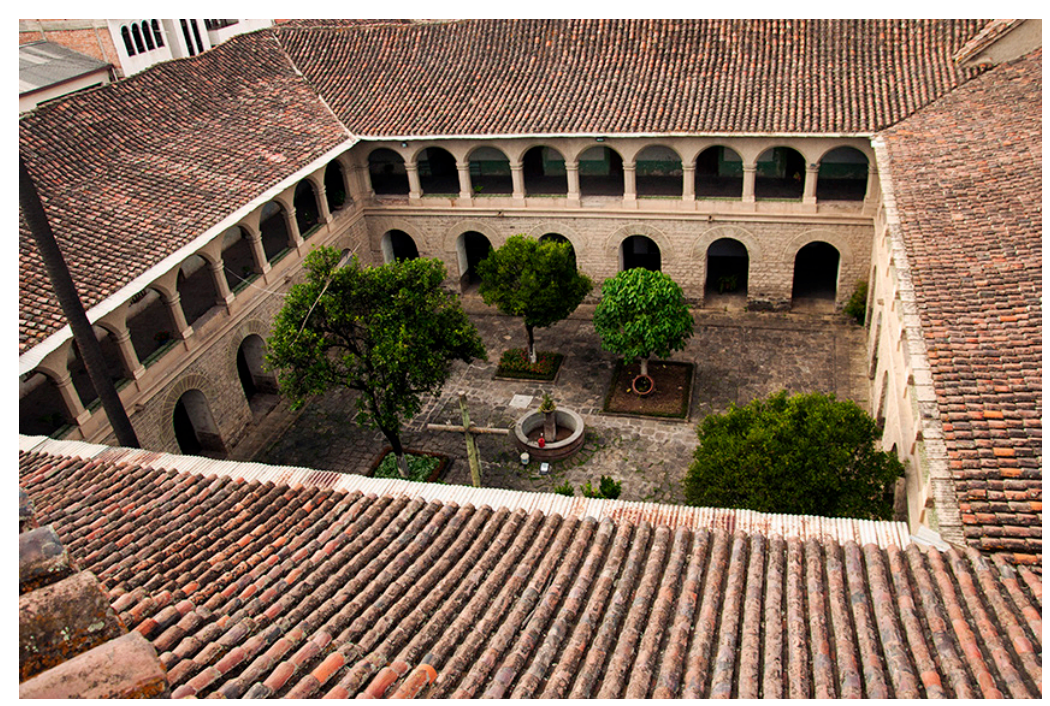

Fonte: Fotografia do Arquiteto Carlos Lavayen, 1980. 
Todos os fatores até aqui expostos foram condicionantes básicos para a elaboração do projeto arquitetônico de intervenção restaurativa. Desde o ponto de vista da adequação funcional do programa da escola e do museu, as soluções se desenvolveram rapidamente. Contudo, o novo volume concebido a partir das ruínas da primeira igreja, que acolheria as aulas de ateliê da escola de artes, representou um grande desafio.

O edifício novo corresponde a uma volumetria de linhas simples, que busca, porém, dialogar com a preexistência através de uma nova cobertura para o espaço que ocuparia a antiga igreja arruinada, mesclando telhados planos com outros com inclinações de $45^{\circ}$. Ela nasce de pilares assimétricos construídos em aço corten, que delimitam o fechamento vertical no qual deveriam estar os muros colapsados do templo. Deste modo, foi possível a recuperação espacial da igreja, mas também o resgate do ambiente do segundo pátio - até o momento perdido, ilegível. (Figuras 3-4)

E, como já foi dito, foi previsto a demolição parcial do muro que corresponde à fachada oeste do complexo arquitetônico com o intuito de liberar a vista do frontispício da igreja arruinada, permitindo a apreciação da bela portada que se esconde por detrás dessas grossas paredes de adobe. O pequeno átrio de frente à fachada principal do antigo templo, resultante das demolições no muro preexistente, servirá como uma transição entre o espaço da rua e a Escola Superior de Artes. (Figuras 5-6)

Finalmente, para igreja neoclássica procurou-se fornecer acesso articulado aos inusitados espaços semiabertos entre suas paredes externas e os muros ondulantes inacabados, bem como conceber um elevador e sistematizar escadas que permitam alcançar o topo das paredes polilobuladas, de onde é possível apreciar a arquitetura de todo o complexo - para além das formas pulsantes do próprio muro. O elevador panorâmico também permitirá o acesso aos pisos superiores do convento através da Capela de Oração. (Figuras 7-8)

Figura 3 - Simulação tridimensional da inserção do volume novo para os ateliês

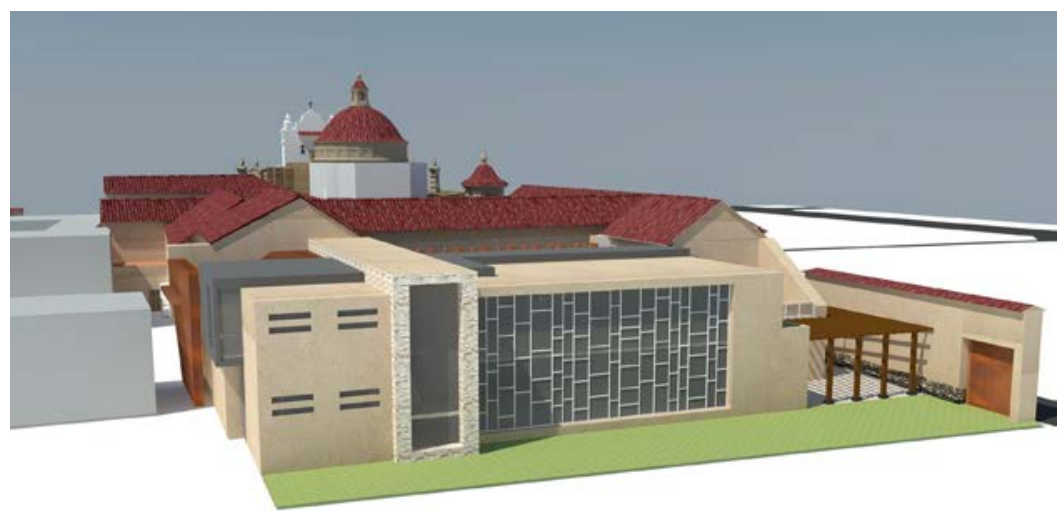

Fonte: Candia Barrientos (2016), com a colaboração de Daniel Avendaño.

Figura 4 - Simulação tridimensional da nova cobertura que encerra as ruínas da primeira igreja e recompõe o segundo pátio.

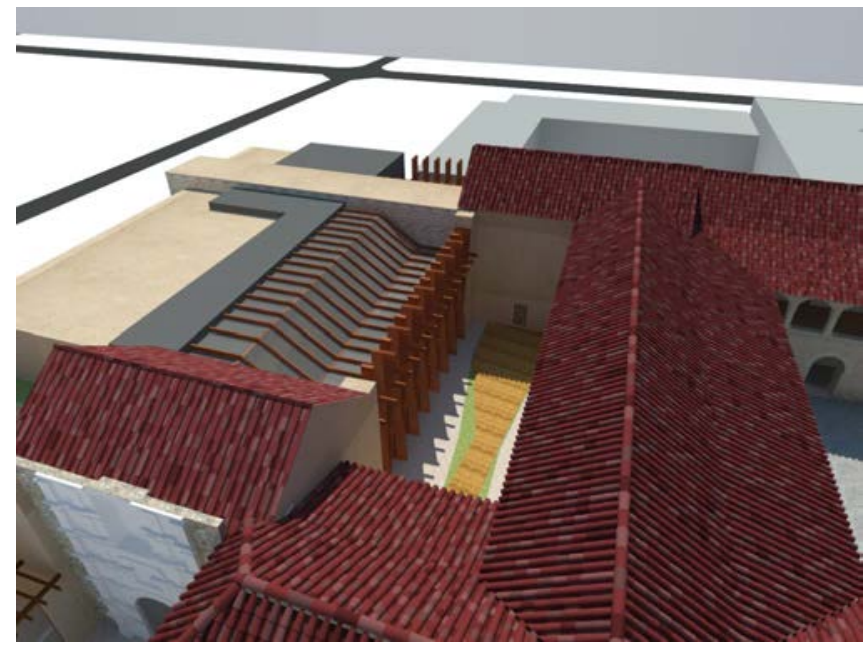

Fonte: Candia Barrientos (2016), com a colaboração de Daniel Avendaño. 
Figura 5 - Simulação tridimensional da fachada da primeira igreja com vista da rua após a demolição de parte do muro oeste.

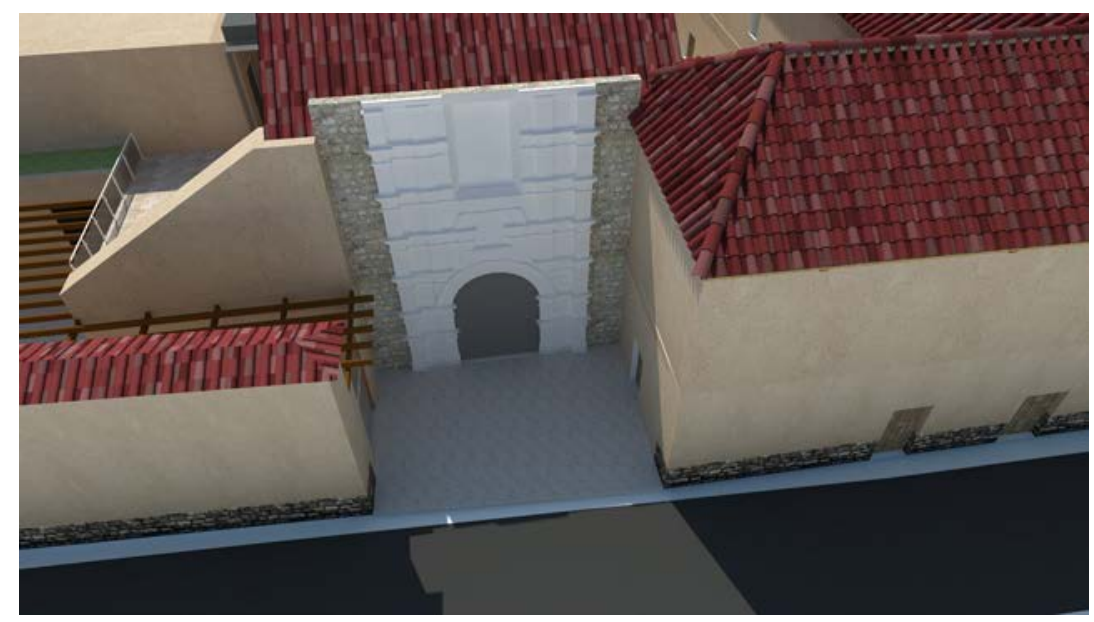

Fonte: Candia Barrientos (2016), com a colaboração de Daniel Avendaño.

Figura 6 - Fachada sul. Proposta para a limpeza e remoção de pintura.
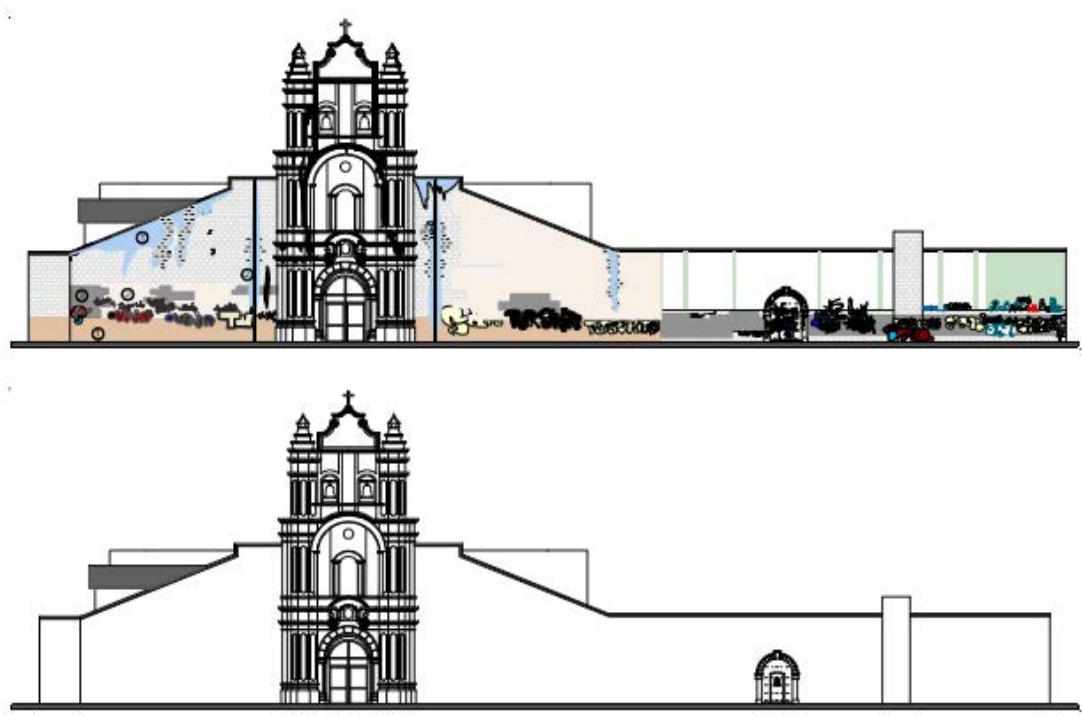

Fonte: Candia Barrientos (2016). Fachadas desenhadas pela autora com base nos planos cedidos pela fundação IMAGEN.

Figura 7 - Corte do setor no qual será assentado o novo elevador para acesso ao topo dos muros curvos.

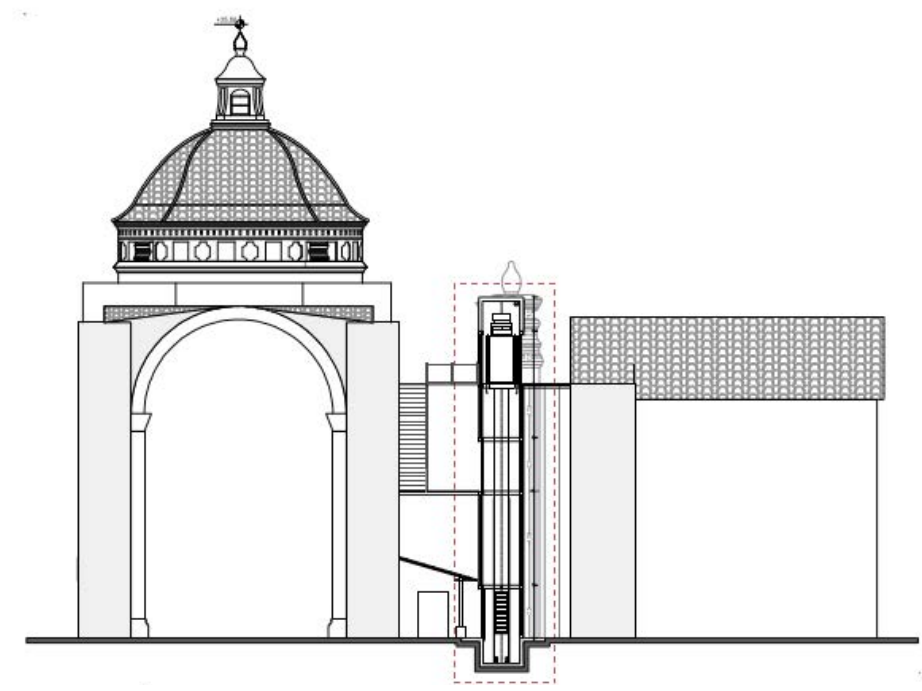

Fonte: Candia Barrientos (2016). 
Figura 8 - Simulação tridimensional da inserção do elevador para acesso ao topo dos muros curvos.

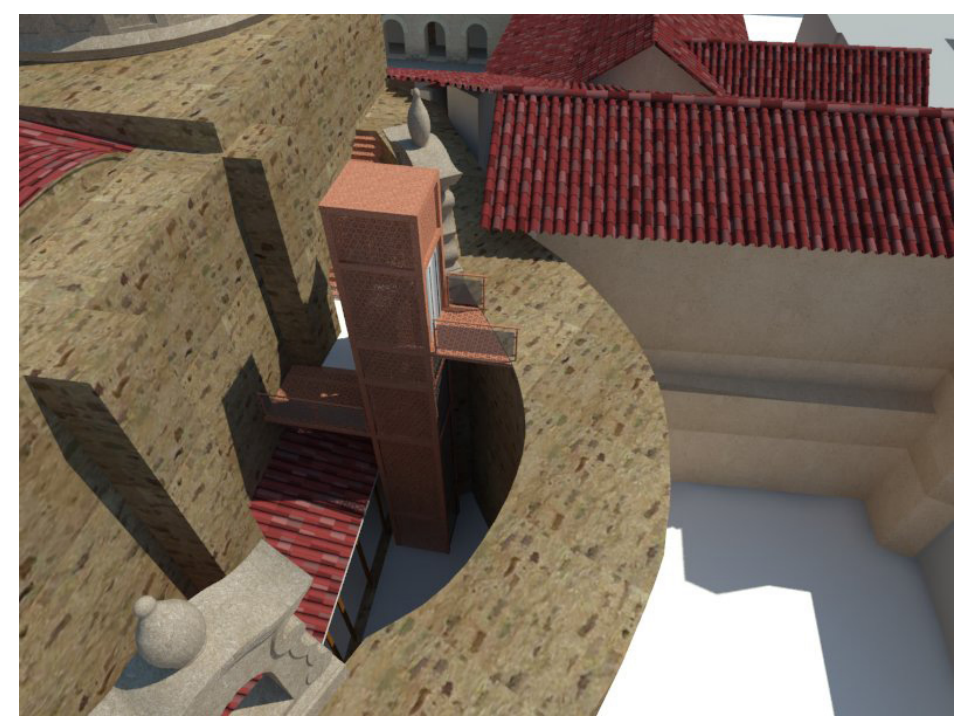

Fonte: Candia Barrientos (2016).

\section{REFERÊNCIAS}

CANDIA BARRIENTOS, Alicia Gabriela. Restauração do Convento de Santa Teresa de Carmelitas Descalzas: projeto para a Escola Superior de Arte, em Cochabamba, Bolívia. Trabalho Final desenvolvido no Mestrado Profissional em Conservação e Restauração de Monumentos e Núcleos Históricos da UFBA. Salvador: MP-CECRE UFBA, 2016.

NOTA DO EDITOR (*) O conteúdo do artigo e as imagens nele publicadas são de responsabilidade do(s) autor(es). 


\title{
DIRETRIZZS PARA A PRESERVACÇÃO INTEGRADA DO CENTRO ANTIGO DE SAN SALVADOR - EL SALVADOR
}

\author{
ESPINOZA, LUZ AMARILY ARAUJO \\ Arquiteta, Mestre, Profissional Autônoma, e-mail: arqlaaespinoza@gmail.com \\ Trabalho Final desenvolvido no Mestrado Profissional em Conservação e Restauração de Monumentos e Núcleos Históricos. \\ Orientadora: Juliana Cardoso Nery \\ Coorientadora: Marcia Genésia de Sant'Anna
}

\section{RESUMO EXPANDIDO}

A literatura e a realidade demonstram que a recuperação de áreas urbanas degradadas, bem como a preservação e valorização de seu patrimônio urbano, são possíveis sob uma abordagem integral e abrangente do problema, em suas múltiplas dimensões, incluindo as dinâmicas e as diferentes escalas a ele relacionadas.

Neste contexto, se insere o Trabalho Final desenvolvido para o MP-CECRE (ESPINOZA, 2015) que tem como base a recuperação do centro antigo de San Salvador, capital de El Salvador, delimitado pelo Decreto de Ordem Municipal $N^{\circ} 25$ e ratificado pelo Decreto de Ordem Nacional $N^{\circ}$ 680, correspondente à cidade construída desde a sua fundação, no século XVI, até a segunda metade do século XX.

A cidade, implantada como parte da estratégia de dominação do território de colonização espanhola, ganha independência no início do século XIX e experimenta um grande crescimento. A partir dos anos cinquenta se inicia um processo contínuo de degradação e esvaziamento da área central. No entanto, como em muitos centros históricos da América Latina, este permanece como testemunho importante da história e da tradição viva de um lugar.

O trabalho tem singular importância na medida em que propõe a elaboração de um panorama que permita entender o processo de transformação do espaço urbano central e de seu patrimônio, buscando interfaces para se esboçar uma política de preservação que venha ao encontro do planejamento e do desenho urbano, e assim, refletir sobre os meios mais adequados para a preservação do patrimônio material e imaterial da área fundacional - lugar que, ao englobar os principais símbolos culturais da cidade, se configura como uma zona de cruzamento de múltiplas identidades e interações, num universo amplo de atores. Logo, se trata de incluir a dimensão socioeconômica e cultural como diferencial para o estabelecimento de diretrizes na área antiga. Ou seja, caracterizar e pensar sobre o processo de permanências e inflexões da produção urbanoarquitetônica, sobre as práticas ocorridas e sobre instrumentos que possam ir além de sua deterioração material, são fundamentais - especialmente quando se agregam aos complexos problemas de preservação o desafio de estabelecer o que e como preservar de um patrimônio urbano e arquitetônico que tanto sofreu com terremotos e catástrofes. Ou seja, Uma materialidade que é frequentemente reerguida entre os escombros e ressemantizada.

Os estudos realizados durante o mestrado profissional, entre 2014-2015, em particular nos Ateliês I, II e III, foram fundamentais para o conhecimento do objeto, dos seus estratos históricos e a compreensão dos problemas, suas causas e consequências, permitindo vislumbrar os possíveis caminhos para reverter, por meio de diretrizes e de uma proposta de intervenção projetual, as problemáticas do lugar.

Para alcançar objetivo geral de recuperar e preservar esse lugar traçaram-se recortes menores, objetivos específicos, a saber:

1. Entender os elementos da cidade, seus processos de produção e suas transformações.

2. Caracterizar as ações de deterioração da área central e as suas intervenções, focalizando o recorte espacial centro antigo de San Salvador. 
3. Levantar, sistematizar e registrar as informações relacionadas com o objeto de estudo.

4. Analisar criticamente as informações levantadas, à luz do referencial teórico adquirido.

5. Elaborar uma metodologia aplicável para a preservação urbana do objeto em estudo nas suas dimensões tangível e intangível.

6. Desenvolver uma experiência projetual pontual onde se reunisse a reflexão teórico-propositiva, considerando a reintegração urbano-arquitetônica de alguns espaços da área em estudo, bem como a reabilitação da área sob a equação sociocultural.

A pesquisa se desenvolveu em diferentes níveis, por um lado, a leitura e determinação de diretrizes macro do objeto - um estudo geral da área definida pelo decreto N680 - Centro Consolidado (Figura 1); por outro, a leitura e proposições micro no perímetro chamado - Centro Ciudad (em destaque na Figura 1), recorte escolhido para maiores aprofundamentos das questões trabalhadas por ser o mais representativo das características, problemáticas e possibilidades da área; por fim uma proposta de intervenção para a Plaza Libertad e para a Feira de Reparos (localizada em uma das faces da praça, que atualmente abriga uma precária feira), onde buscou-se consonância com as preexistências ambientais, logo, a recuperação da loggia do Antigo Cabildo.

Figura 1 - Delimitação territorial conforme decreto №680. Em destaque, área de estudo da investigação.

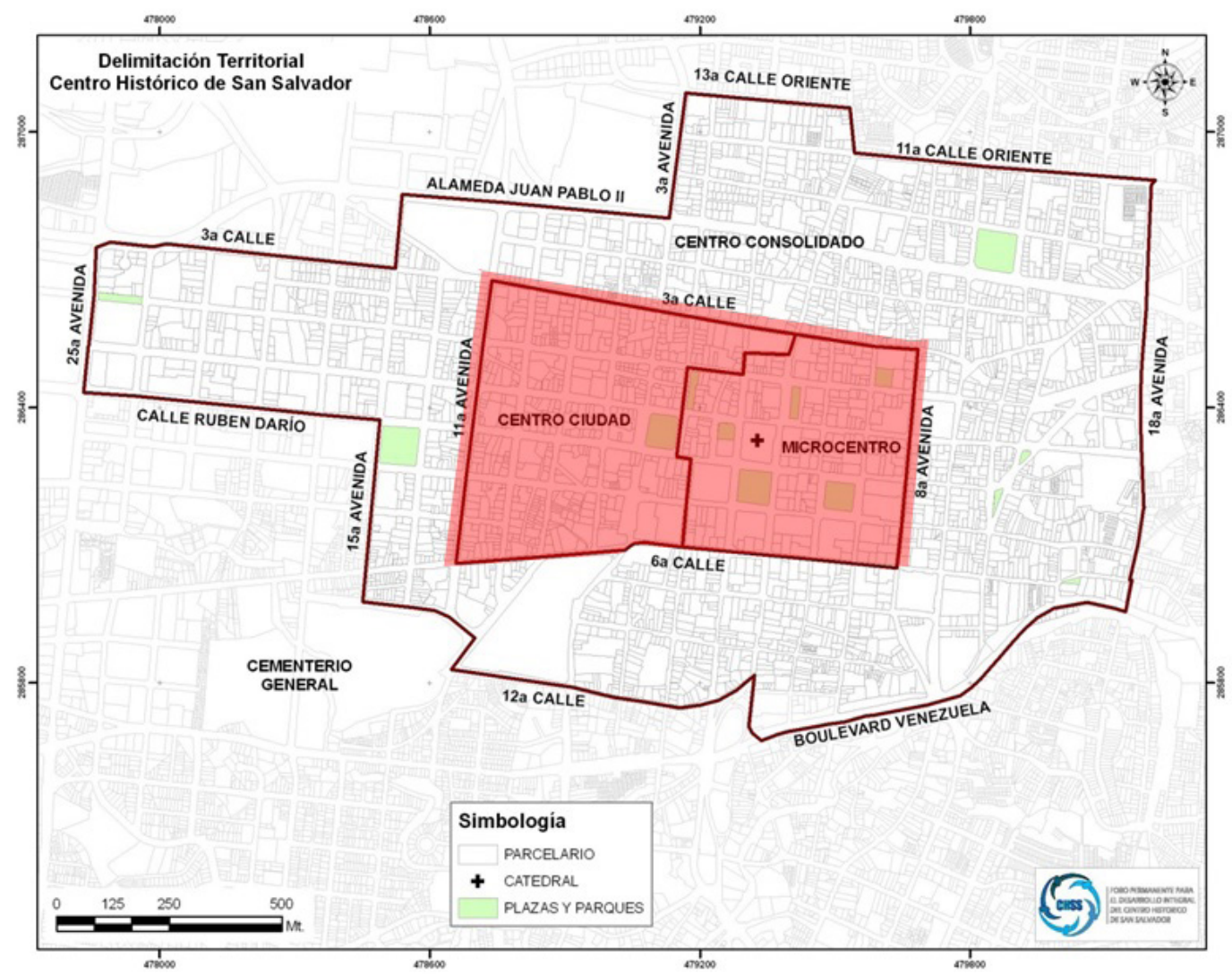

Fonte: Elaboração própria a partir da imagem de FUNDASAL (2010).

Os levantamentos e diagnóstico criteriosos deram subsídios para a elaboração da metodologia adotada e permitiu a criação das Unidades Dinâmico-Morfológicas (UDM), instrumento de identificação de áreas urbanas de interesse de preservação, que se apoia no entendimento da cidade como uma experiência concreta e que tem como intuito relacionar as diversas dimensões do patrimônio - as formas de apreensão do espaço, a morfologia e dinâmica urbanas (estrutura, função e paisagem), o conhecimento profundo da história e dos processos nele ocorridos, o sentido e valores que os seus sujeitos the atribuem. 
Desse modo, a proposta de diretrizes e o projeto giraram em torno dos valores e das possibilidades metodológicas de aproximação e apreensão do espaço urbano, a partir da complexa e imbricada relação entre materialidade e imaterialidade que constituem um determinado lugar e o fazem merecedor de ações e instrumentos de preservação. Vários autores como Sant'Anna (2011) e Rapoport (1978) chamam a atenção para a inseparabilidade entre esses dois aspectos, e colocam como exemplo as diversas manifestações de cunho imaterial, cujas representações de valores de natureza simbólica fazem referência à base tangível, ao suporte material. Dando continuidade a essa linha de pensamento, pode-se entender que a cidade e os seus artefatos - arquitetura e equipamentos urbanos, vão além da materialidade de formas e configuração de espaços - pois são portadores de significado e suporte gerador de identidades, afeições, memórias e imaginários. Nesse sentido as cidades, em especial seus centros antigos, constituem exemplo e exercício privilegiado de reflexão sobre o patrimônio cultural, não apenas pela indivisibilidade entre o material e imaterial, como também, e ainda mais, pela complementaridade desses aspectos. Assim, por meio do caso específico do Centro Antigo de San Salvador em El Salvador e suas UDM, foi possível contornar questões difíceis e em muitos casos novas para o patrimônio, sendo necessário considerar e entender a estrutura urbana e suas características arquitetônicas (Figuras 2-3), a vulnerabilidade física do sitio perante os desastres naturais, a complexidade da dinâmica informal, o avançado grau de deterioro e abandono da estrutura edilícia, a inclusão e pressão exercida pelos novos atores e funções.

Figura 2 - Implantação da cidade de San Salvador aos pés do vulcão de Quezaltepec.

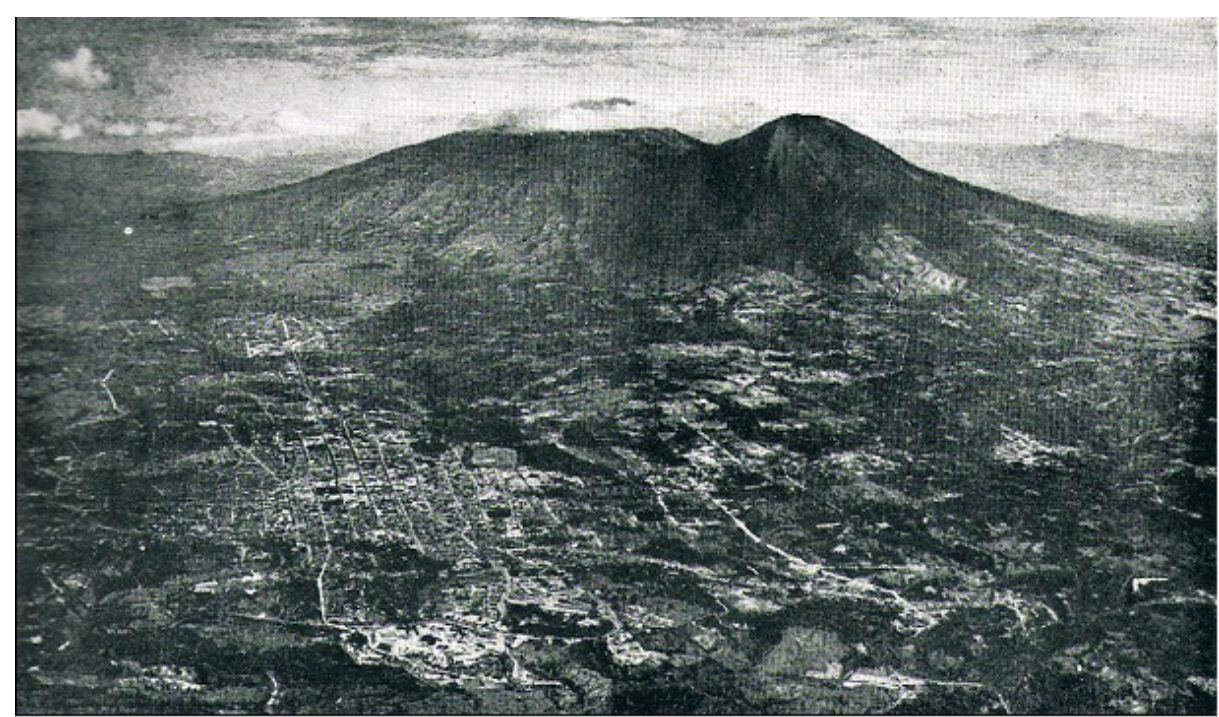

Fonte: Castro (1950).

Figura 3 - Centro antigo de San Salvador em 1950. Na imagem é possível observar o traçado e a convivência no seu núcleo inicial (primeiro plano) de diferentes tempos arquitetônicos.

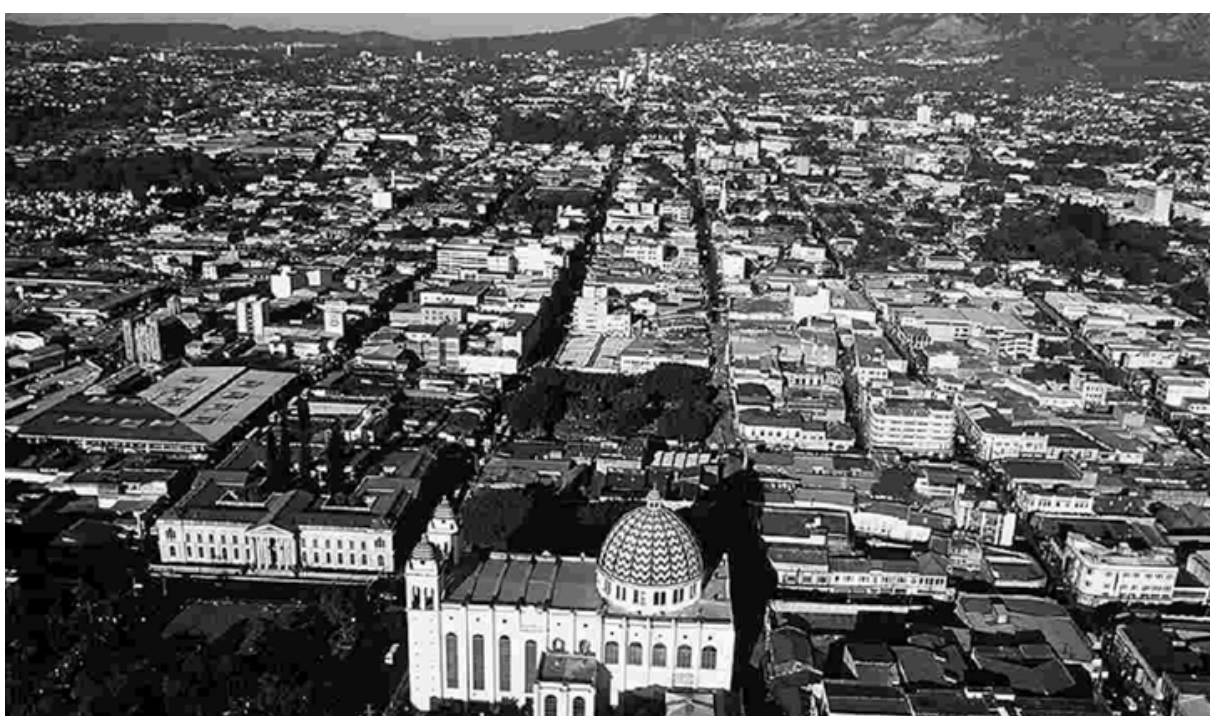

Fonte: Tripadivisor (2009). 
Espera-se que as UDM possam sugerir um caminho que considere as relações entre o patrimônio edificado, os aspectos da cultura e a economia local, os significados da cidade em relação às características do lugar, a sua conformação e transformação no tempo, aquilo que de algum modo dá sentido de permanência e memória, mas, não impede de pensar e viver a cidade mutável, como um lugar de profunda transformação como assinalado por Fernando Carrión (2013).

Consequentemente, as diretrizes de intervenção e conservação para área de estudo foram elaboradas a partir das problemáticas identificadas por meio das UDM. Através desse instrumento foram redenhados os limites para o perímetro inicialmente proposto pelo decreto $N^{\circ} 25$ e $N^{\circ} 680$ (Figura 4), configurandose seis subáreas. Estabeleceram-se tópicos fundamentais no tocante à estrutura urbana e edilícia, formulando disposições sob 8 eixos de trabalho, organizados em 3 grandes níveis: Macro - Ambiências e entorno; Intermediarias - Mobilidade, Espaços públicos, Infraestrutura; Micro - Morfologia, Acervo Edilício, Uso do Solo, Patrimônio Imaterial, assim como um ensaio projetual para uma das UDM.

Figura 4 - Esquema Unidade Dinâmico-Morfológica (UDM).

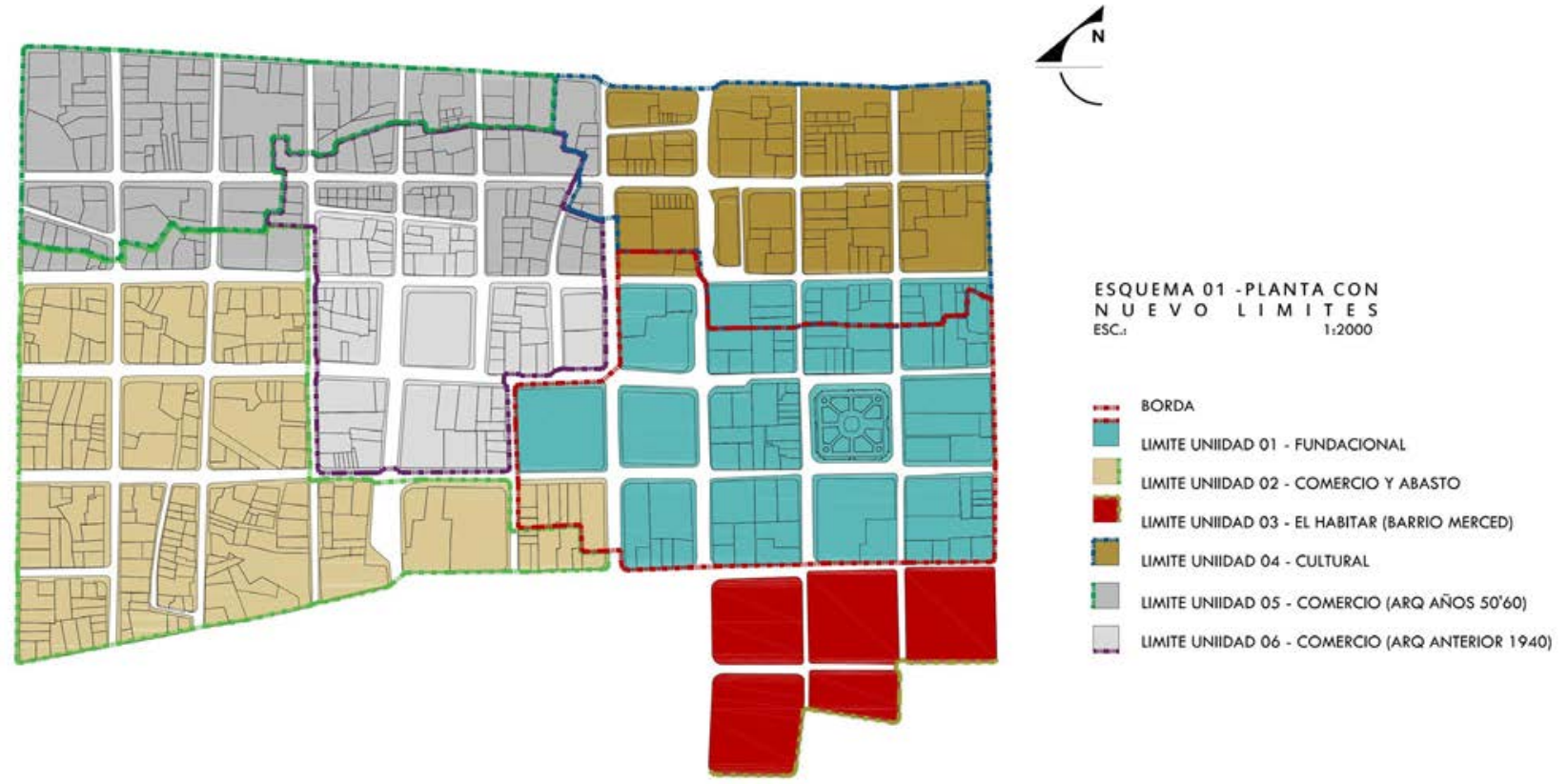

Fonte: Espinoza (2015).

No ensaio projetual, objetivou-se materializar o pensamento vindo das diretrizes. Nesse contexto trabalhou-se com a UDM 01 - Área Fundacional (Figura 5), cujo objetivo principal era a reintegração da paisagem parcialmente fraturada pela incompletude de uma de suas quadras (a do Antigo Cabildo) através de um novo projeto - a Feira de Reparos (Figura 8) e pelo resgate da Plaza Libertad (antiga Plaza Mayor) através do seu redesenho (Figura 7).

Também, buscou-se que os projetos sustentassem a dinâmica econômica do lugar, estruturando e dando condições para a informalidade, condicionando espaços para fortalecer suas manifestações culturais e incentivando usos (habitar, institucional, comercio, serviços) (Figura 6). Finalmente, espera-se que as medidas e ações descritas contribuam para dinamizar e configurar o centro como um lugar de coletividades. 
Figura 5 - Ficha de caracterização e análises UDM 01 - Fundacional.

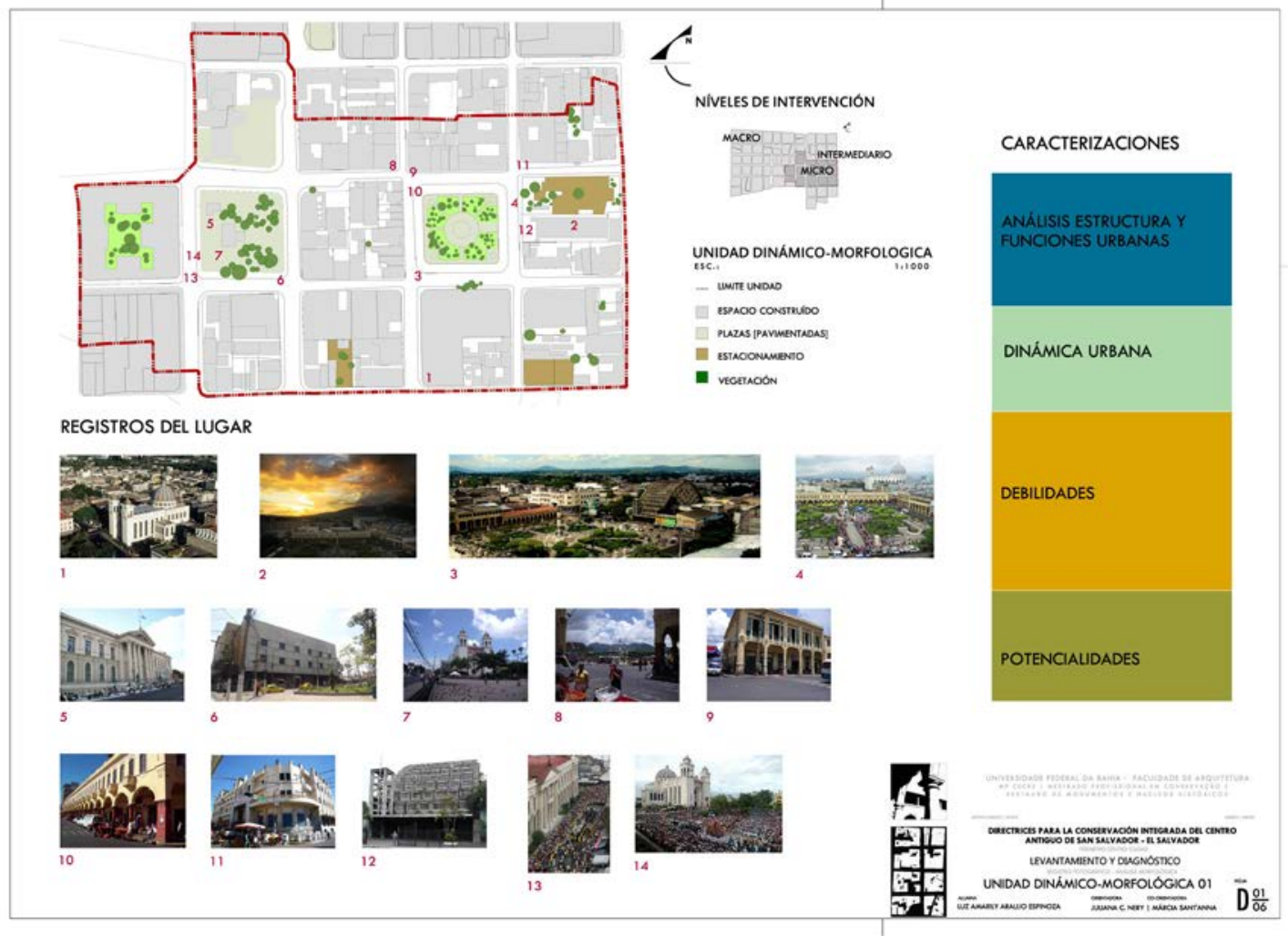

Fonte: Elaboração e montagem da autora a partir de SECULTURA (2012).

Figura 6 - Planta de usos propostos para UDM 01 - Fundacional.

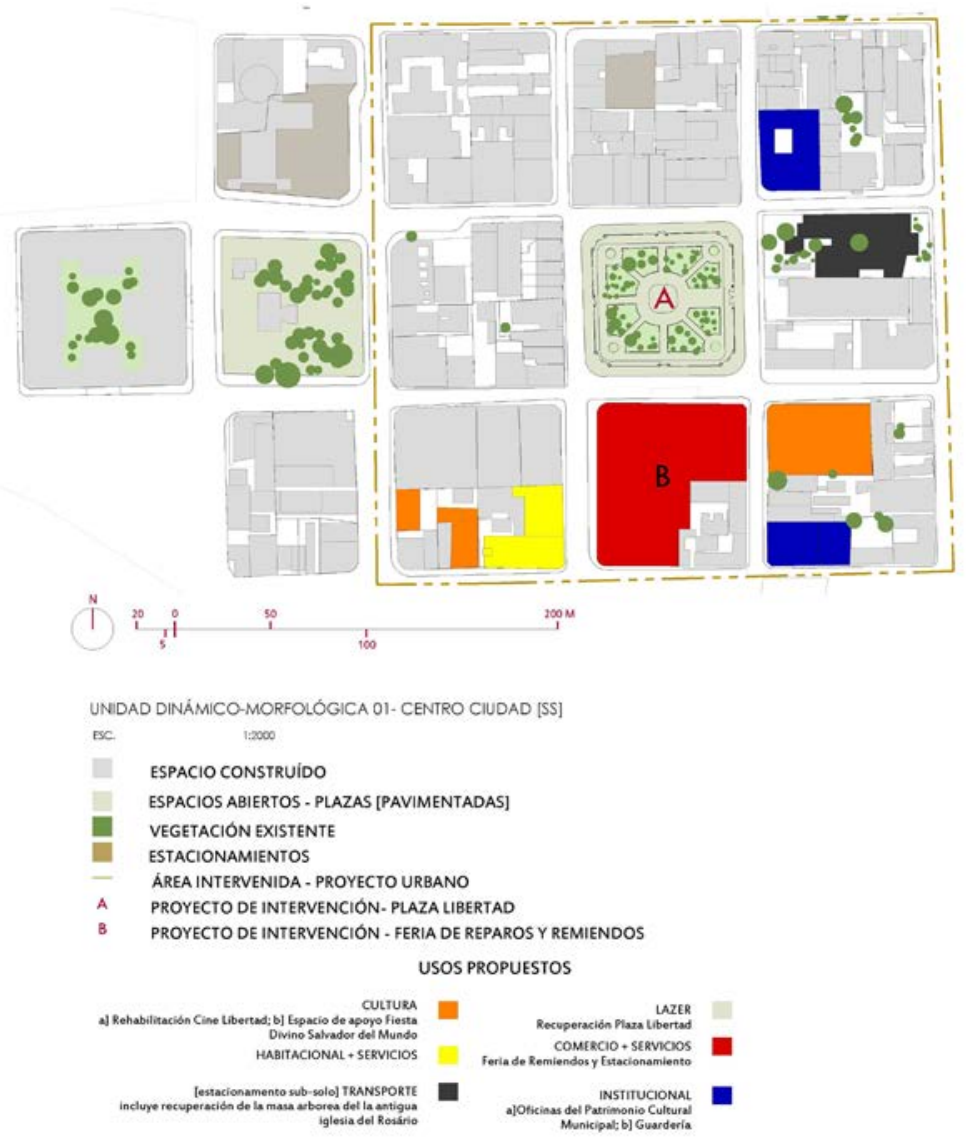

Fonte: Espinoza (2015). 
Figura 7 - Proposta de intervenção para a Plaza Libertad (Plaza Mayor).

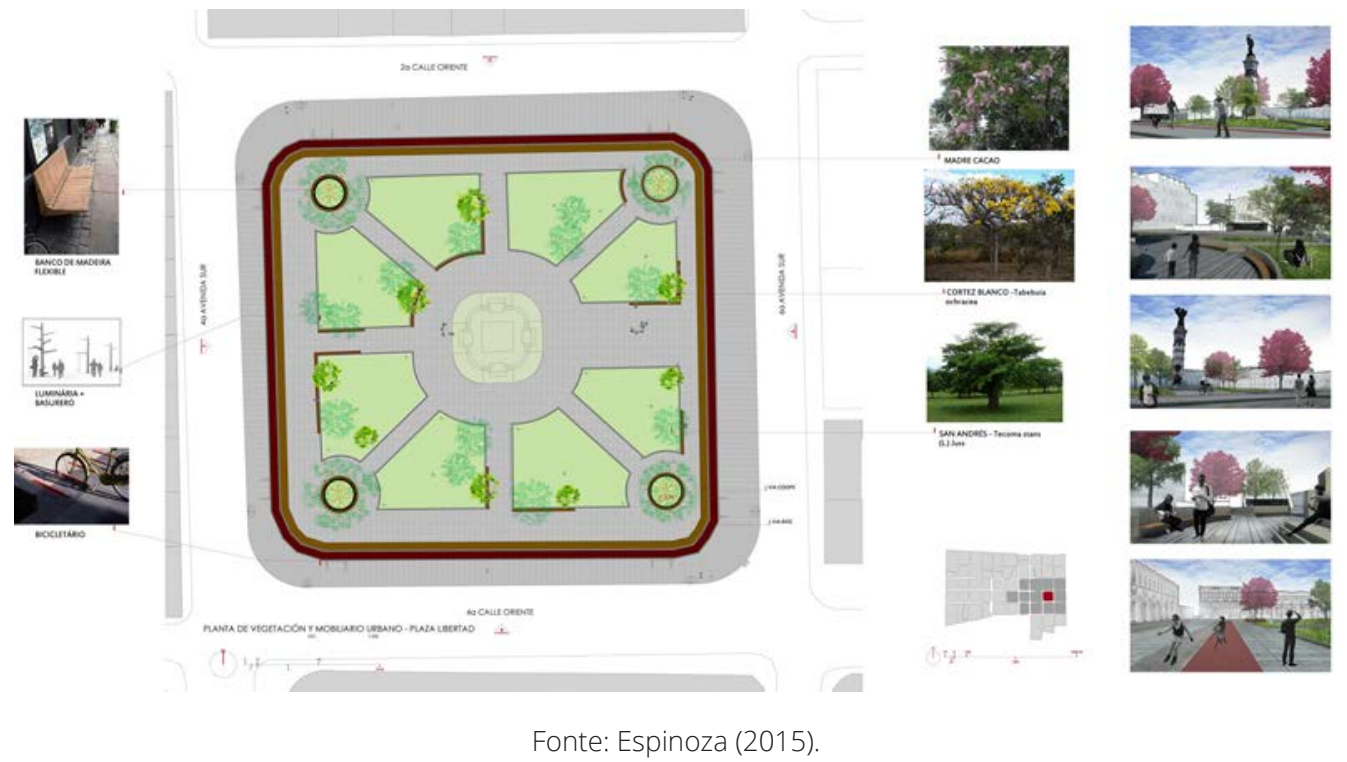

Figura 8 - Perfiles para a UDM 01 - Fundacional. Inserção das propostas de intervenção - Feira de Remendos. Reparos e Redesenho da Plaza Libertad.

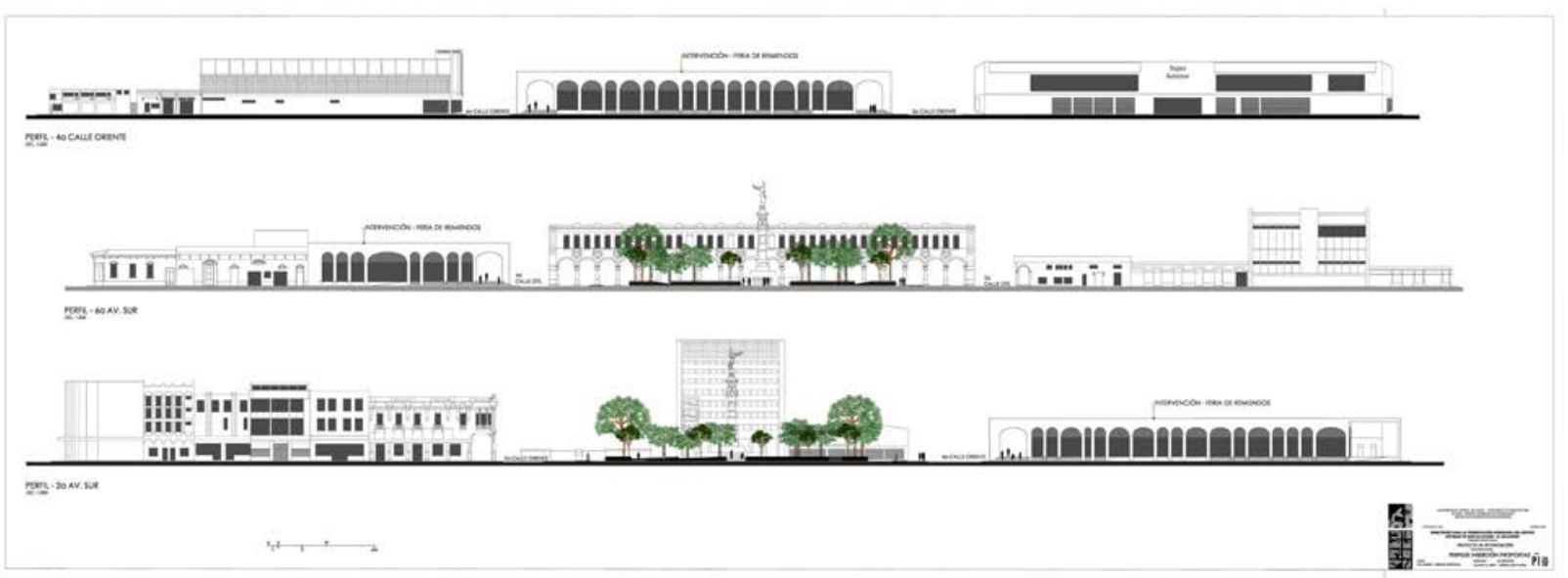

Fonte: Espinoza (2015).

\section{REFERÊNCIAS}

BARON, Rodolfo. Reseña histórica de la Villa de San Salvador: desde su fundación (1525) hasta que recibe el título de ciudad (1546). Madrid: Ediciones Cultura Hispánica, 1950.

ESPINOZA, Luz Amarily Araújo. Directrices para la preservación integrada del centro antiguo de San Salvador - El Salvador. 11 de dez 2015. 550 f. Trabalho Final desenvolvido no Mestrado Profissional em Conservação e Restauração de Monumentos e Núcleos Históricos da UFBA. Salvador: MP-CECRE UFBA, 2015.

Fundación Salvadoreña de Desarrollo y Vivienda Mínima (FUNDASAL). Centro Histórico de San Salvador, nuestro reto pendiente. San Salvador: FUNDASAL, 2010.

CARRIÓN, Fernando. DERECHO de la Ciudad: el antídoto al urbicidio. Conferência. Disponível em: https://www.youtube.com/watch?v=dk7n1 NyltTM RAPOPORT, Amos. Aspectos humanos de la forma urbana. Barcelona: Gustavo Gili, 1978.

SANT'ANNA, Márcia. Patrimônio material e imaterial: dimensões de uma mesma ideia. In: GOMES, Marco Aurélio de Filgueiras; CORRÊA, Elyane Lins. Reconceituações Contemporâneas do Patrimônio. Salvador: EDUFBA, IAB, 2011, p. 193-198.

Secretaría de Cultura de la Presidencia (SECULTURA). Base Cartográfica. San Salvador: SECULTURA, 2012.

TRIPADVISOR. Disponível em: https://www.tripadvisor.com/LocationPhotoDirectLink-g294475-i19571216-El_Salvador.html\#19571214. Acessado em 05 de maio de 2014.

NOTA DO EDITOR (*) O conteúdo do artigo e as imagens nele publicadas são de responsabilidade do(s) autor(es). 


\section{REQUALIFICAÇÃO DA ANTIGA ESTAÇ̃̃O RODOVIÁRIA DE SALVADOR}

\section{FREIRE, RAQUEL NEIMANN DA CUNHA}

Arquiteta, Mestre, Profissional Autônoma, Professora da FAUFBA, e-mail: quelneimann@gmail.com Trabalho Final desenvolvido no Mestrado Profissional em Conservação e Restauração de Monumentos e Núcleos Históricos. Orientador: Nivaldo Vieira de Andrade Junior Coorientadora: Mariely Cabral de Santana

\section{RESUMO EXPANDIDO}

A primeira Estação Rodoviária de Salvador, nas imediações do centro tradicional, guarda capítulos especiais pouco conhecidos da história da cidade e da arquitetura soteropolitanas. Primeiro edifício em concreto protendido da Bahia, foi projetado de Diógenes Rebouças e Assis Reis, construído em 1963 em onze meses, num importante momento de urbanização modernizadora e rodoviarisita - equipamento estratégico para a capital e para o Estado (Figura 1). Seu grande arrojo técnico, volumétrico e plástico não foi suficiente para impedir o descaso e a degradação desde a desativação do seu uso original, após onze anos de funcionamento, chegando-nos hoje atrofiado, desfigurado e deficiente (Figura 2).

Figura 1 - O protagonismo do edifício na paisagem em construção.

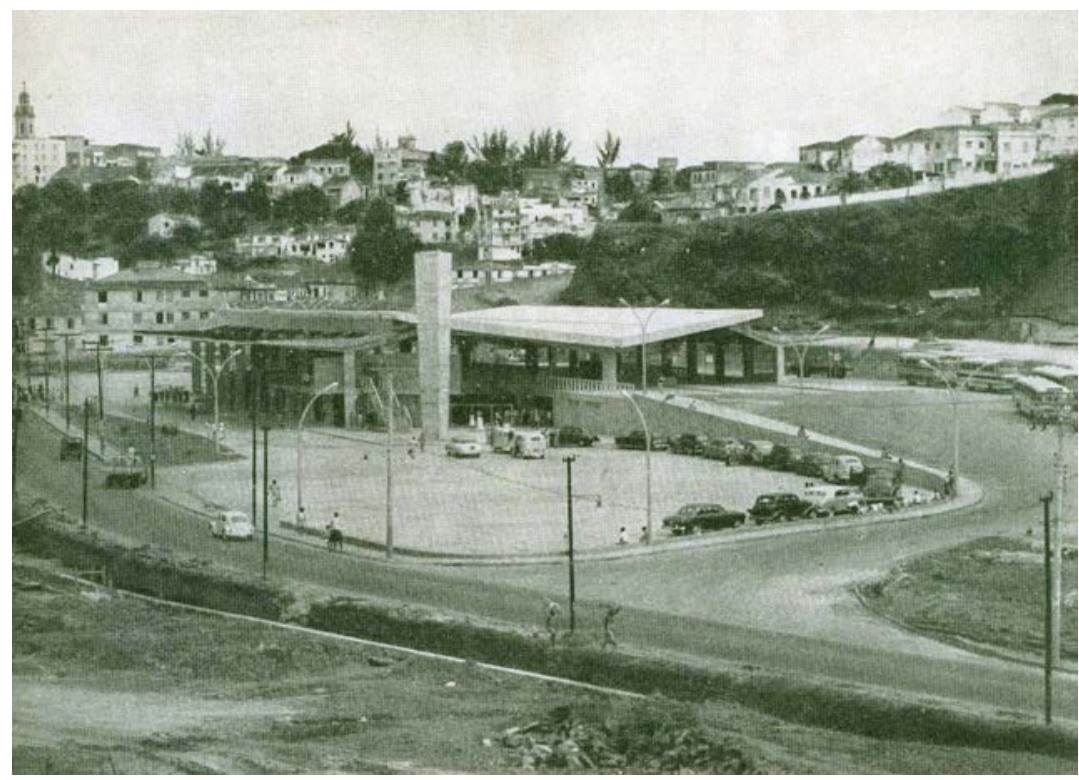

Fonte: Centro de Documentação e Referência Odebrecht.

Figura 2 - Vista panorâmica da antiga Rodoviária nos dias de hoje.

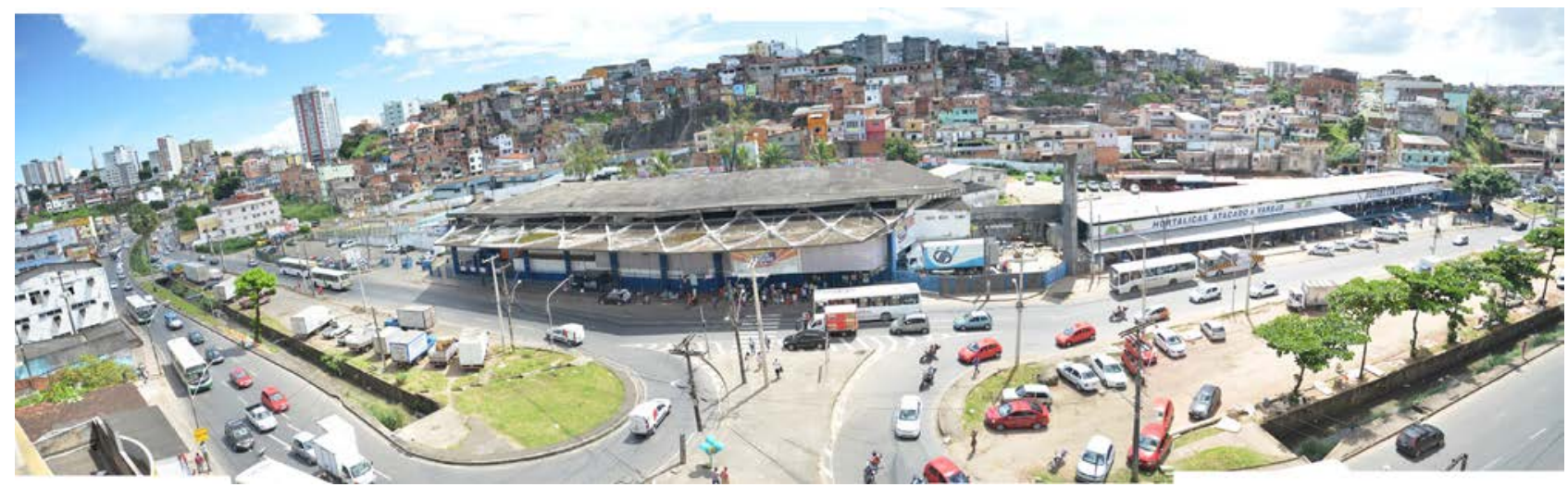

Fonte: Fotografia de Maria Emília Regina, 2014 
Abrigando, em 1974, o mercado da COBAL, muitas modificações contribuíram para sua descaracterização, em relação à cidade e à sua espacialidade. Hoje conhecido como "Cesta do Povo das Sete Portas", os processos de aproximação e registro do edifício, na ausência de qualquer espécie de desenho, exigiram uma busca exaustiva por fotos e textos, um cadastro minucioso e estudos pormenorizados das informações obtidas, sempre intercruzadas.

Ultrapassando questões arquitetônicas, com demandas urbanas, funcionais e sociais, intervir no edifício (FREIRE, 2015) implica repensar essa fração de espaço citadino, sua ocupação e funções; imagem, fluxos e dinâmicas.

Num lote de $17.000 \mathrm{~m}^{2}$, o edifício foi concebido como protagonista absoluto. Aberto para o entorno, agenciava simultaneamente interno/externo, construído/natural, cidade/bairro. As generosas dimensões das áreas externas organizavam fluxos, passageiros e trânsitos, servindo principalmente para estabelecer o recuo das construções vizinhas, necessário para apreensão do edifício: o transeunte estaria distante o suficiente para seu ângulo de visão capturar uma amostra da grandiosidade da cobertura e do seu espaço.

Para reconquistas esse território, extrapolando o edifício para a cidade, se definiu como condição essencial a demolição das precárias construções situadas nas áreas supracitadas, para se poder resgatar o destaque da Antiga Rodoviária. Por outro lado, deslocar a via que a alimenta é gesto de reapropriação das suas dimensões; transeuntes terão uma impressão mais generosa, sendo possível contemplá-la, aproximar-se, conquistar o espaço entre tráfego e permanência.

Além das remoções, para evitar futura proliferação de construções alheias à Estação, propõe-se o projeto de quatro praças ao redor do edifício: abraçando-o, consolidam os limites do terreno, reforçam seu caráter público e suprem uma carência por áreas verdes de lazer na região (Figura 3). Esse "oásis" em meio a tanto asfalto incentiva a identificação do patrimônio, presente no cotidiano dos soteropolitanos, como merecedor de preservação. Delgadas marquises (cuja estrutura é uma releitura da cobertura da Rodoviária) emolduram as praças, convidando ao seu adentramento e permitindo diversas apropriações (anfiteatros, feiras livres, anteparos para ócio/lazer contemplativos...). Sob uma ampliação das marquises, relocamos os pequenos comércios situados nos acréscimos demolidos.

Figura 3 - Vista geral do projeto para a Estação Rodoviária, com seus limites reestabelecidos, praças e marquises.

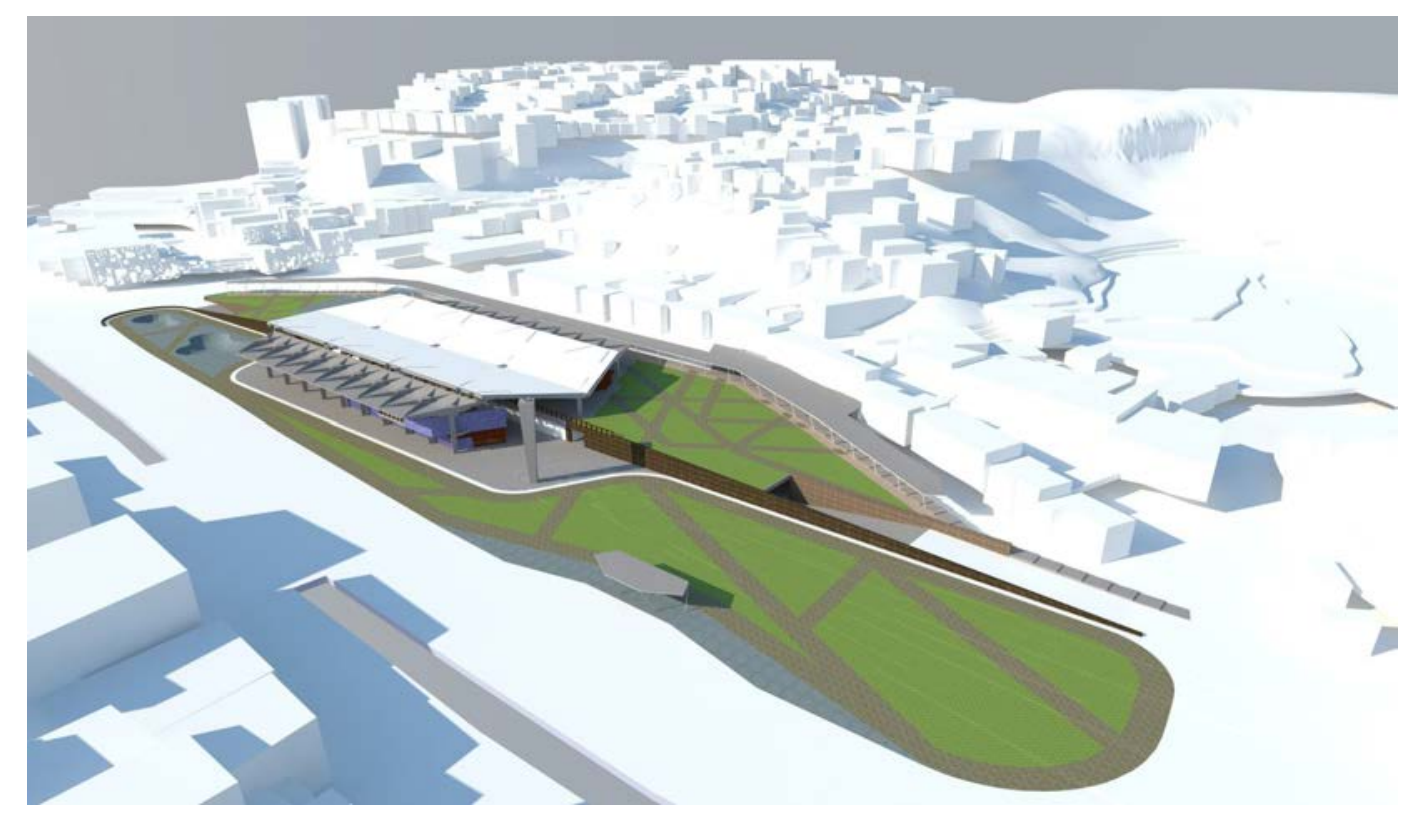

Fonte: Freire (2015). 
Num circuito que se articula funcionalmente com o Mercado das Sete Portas, o projeto (Figuras 4-5) busca relações também com seu entorno, fortalecendo o mercado e a feira de rua como espaços públicos legítimos. Ampliando o uso de feira e mercado no edifício e mantendo a Cesta do Povo, ressaltamos a necessidade da readequação desta à preexistência, recuperada quanto a patologias, espacialidade, plasticidade e permeabilidade, garantindo e conciliando sua condição de monumento e entreposto comercial.

Figura 4 - Planta baixa do térreo: 1. Estacionamento; 2. Sanitários/Vestiários; 3. Floricultura e acesso às rampas; 4. Rampas; 5. Administrações; 6. Depósito "Hort-frut Feirão"; 7 . Depósito Feira Térrea; 8 . Depósito Cesta do Povo; 9

Depósito Feira Pav. Superior; 10 . Praça para Skate; 11. Feira "Hortaliças Atacado e Varejo"; 12 . Loja "Hort-frut Feirão"; 13. Caixa d'água; 14 . Praça para Ciclovia e Caminhadas.

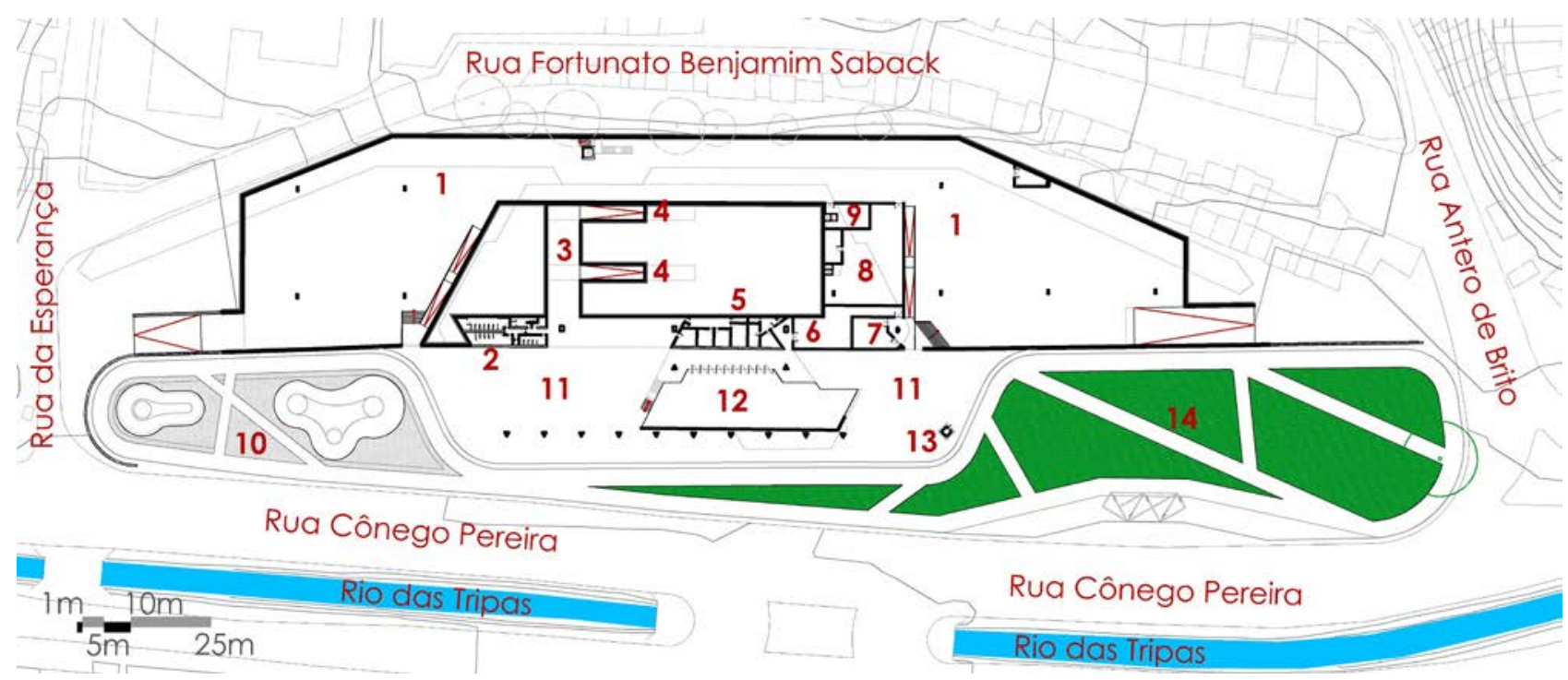

Fonte: Freire (2015).

Figura 5 - Planta baixa do primeiro pavimento: 16. Marquises; 17 . Botecos; 18 . Quadra poliesportiva; 19. Praça inclinada; 20 . Loja Cesta do Povo; 21 . Feira; 22 . Administração Escola-oficina; 23. Cozinha Escola-oficina; 24. Restaurante e Loja Escola-oficina; 25 - Caixa d'água.

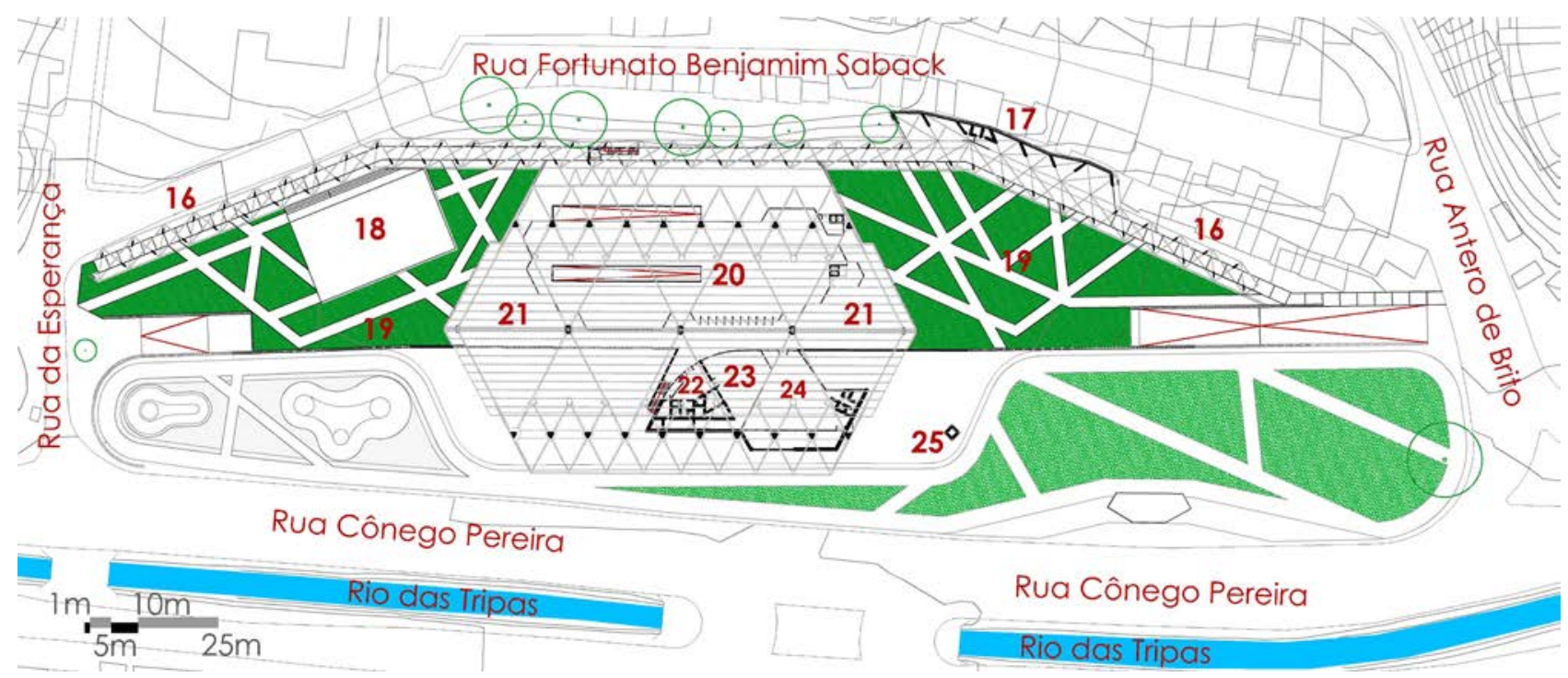

Fonte: Freire (2015).

"Para instância que nasce da artisticidade da obra de arte, o acréscimo reclama a remoção" (BRANDI, 2004, p. 83). Antes de reordenar o programa dentro do edifício (um especial desafio), faz-se premente a liberação dos acréscimos danosos, retomando a continuidade espacial horizontal - generosos e infindáveis vãos - e vertical - comunicação entre os pavimentos com pé-direito duplo e mezanino (Figura 6). 


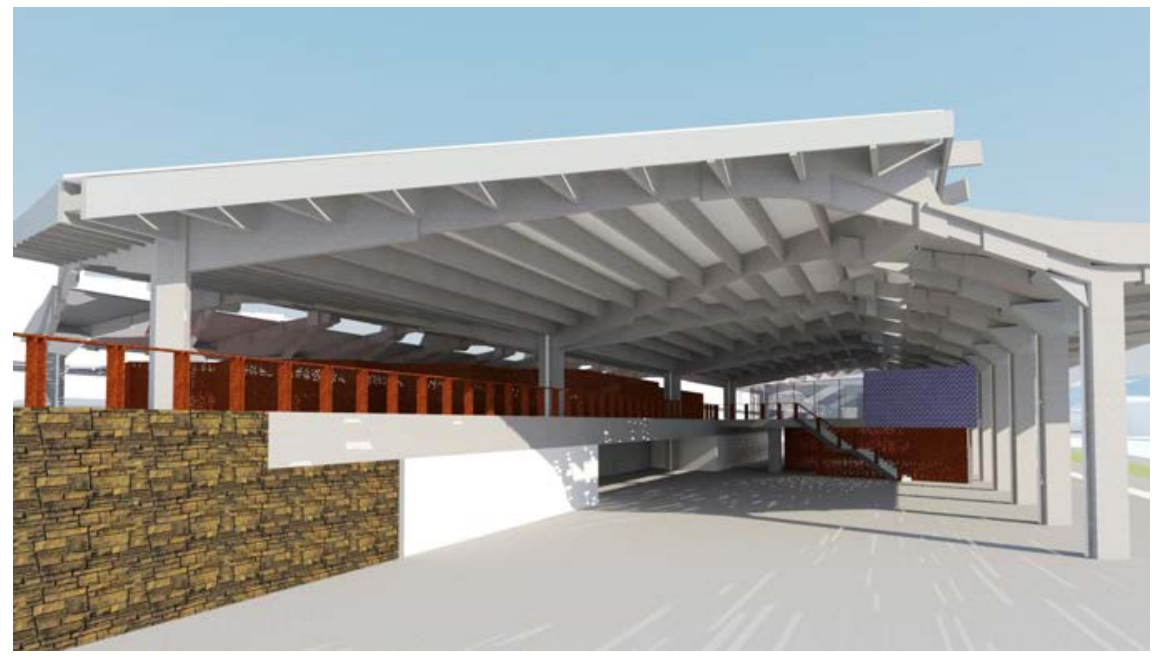

Fonte: Freire (2015).

A articulação entre os pavimentos, originalmente realizada por duas rampas semienterradas (que conduzia os pedestres para as plataformas) e duas escadas, é reestabelecida: desentaipamos e recuperamos as rampas; uma escada metálica preenche a ausência da escada principal da Estação. As praças rampadas completam a circulação do conjunto.

Novos elementos projetuais (expressões contemporâneas em matéria, forma e técnica) são dispostos para garantir a unidade do todo, reforçando as qualidades do bem restaurado - suas relações umbilicais estrutura/espaço, construção/ vazio. Direcionando fluxos, painéis em aço corten perfurado restringem possíveis furtos de mercadorias, mas permitem a passagem de luz, estabelecendo interfaces fluidas, mutáveis pela iluminação.

Áreas obrigatoriamente fechadas (por privacidade ou controle) não se conformam como barreiras ao deslocamento ou ao olhar; delimitam caminhos, direcionando para alargamentos e aberturas. Seus acessos, oblíquos, não interrompem as superfícies contínuas, acontecendo nas proximidades dos pilares.

Nas áreas de pé-direito duplo, uma grande feira se desenvolve. Seu mobiliário responde às necessidades de guarda, controle e exposição dos produtos, além da não interrupção do espaço unificado.

No pavimento superior, painéis fecham a Cesta do Povo, "dançando" conforme a estrutura da cobertura. Medindo 2,50m, contornam pilares, criando novas possibilidades de percebê-los. Sem lajes ou forros, garantem a continuidade do espaço "aéreo", incentivando a curiosidade sobre como nascem aqueles ramos de concreto que voam por sobre o lugar como asas (Figura 7). Também o mobiliário respeita a integridade visual, com as mercadorias alcançando 1,20m de altura.

Figura 7 - Em primeiro plano, os painéis da loja da Cesta do Povo, preservando a continuidade espacial; em segundo plano, junto à escada, as divisórias / vitrines da escola-oficina de culinária e sua loja.

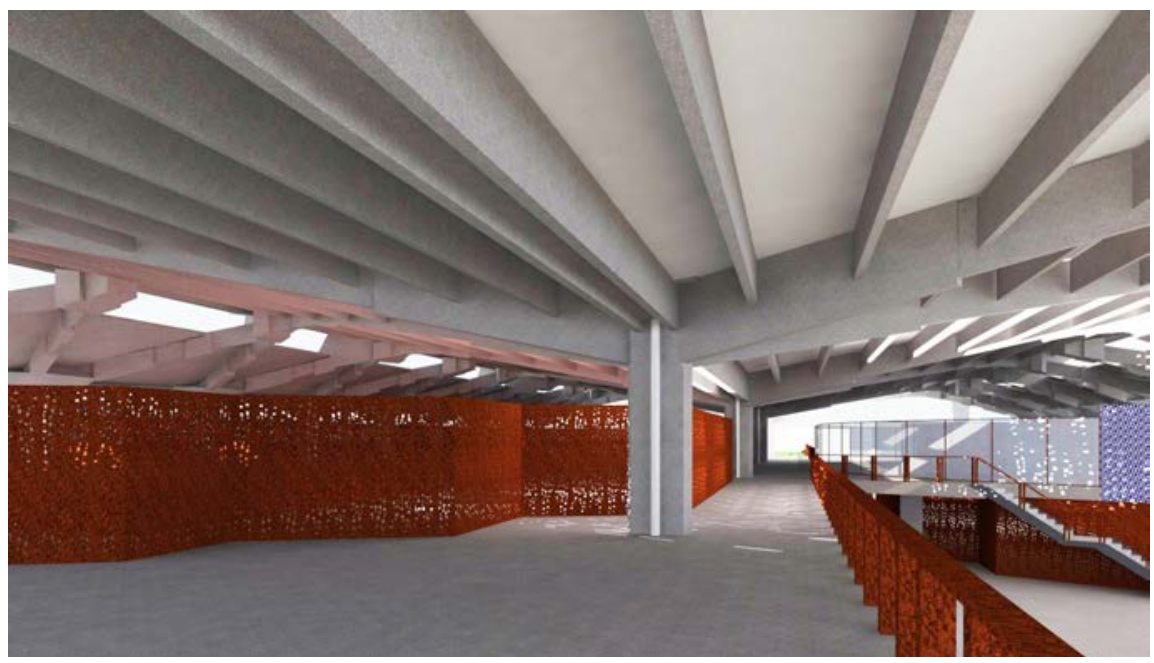

Fonte: Freire (2015). 
$\mathrm{Na}$ fachada sudeste, retomamos a diferenciação dos volumes (revestidos com azulejos do ceramista alemão Udo Knoff), reabrindo o vão da antiga esquadria em fita (Figura 8): o corten dos painéis ao fundo realça o azul da cerâmica.

Figura 8 - Vista da fachada sudeste: o painel de azulejos e o novo anteparo em aço corten.

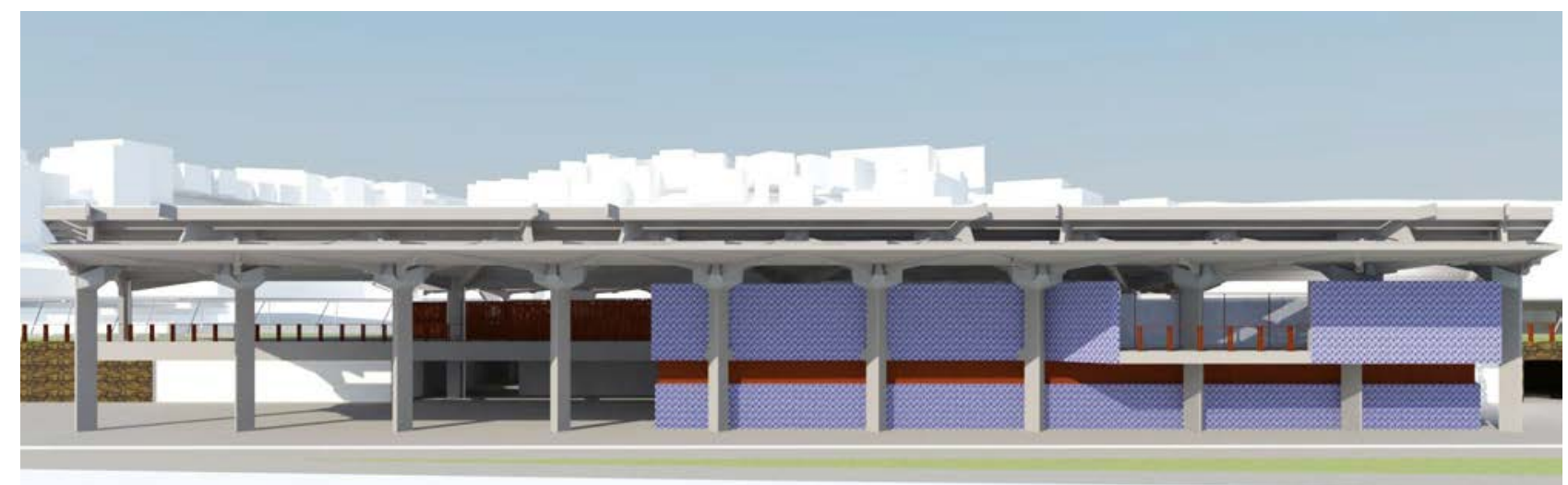

Fonte: Freire (2015).

Quanto aos acabamentos (a maioria em corten), guarda-corpos são releitura dos originais; uma tabeira faz o fechamento dos topos das vigas longitudinais; chapas no topo da estrutura impedem que a numerosa tubulação para drenagem das coberturas periféricas tome posição de figura na captação e condução da água pelo tubo de descida principal, paralelo ao pilar.

\section{REFERÊNCIAS}

BRANDI, Cesare. Teoria da restauração. Cotia: Ateliê Editorial, 2004.

FREIRE, Raquel Neimann da Cunha. Requalificação da antiga Estação Rodoviária de Salvador. Trabalho Final desenvolvido no Mestrado Profissional em Conservação e Restauração de Monumentos e Núcleos Históricos da UFBA. Salvador: MP-CECRE UFBA, 2015.

NOTA DO EDITOR (*) O conteúdo do artigo e as imagens nele publicadas são de responsabilidade do(s) autor(es). 